\title{
Faḍlallāh Al-Hurūfī and His World: Power, Religion, and Sufism
}

\author{
Fatih Usluer*
}

\begin{abstract}
This article discusses Faḍlallāh al-Hurūfî’s relations with political and religious circles in detail from his early youth when he left Astarabad, until his execution at the behest of Mīrānshāh, Timur's son, in 796/1394. The common opinion of why Faḍlallāh was executed is considered to be either his superstitious ideas or his pursuit of some messianic, and thus power-related, goals. We tried to find some clues to confute such stereotypical approaches. To this end, we tried to determine Faḍlallāh's view and stance in regard to power by taking into consideration his relationships with statesmen. It was the 'ulamā' and the sufis who played the most critical and significant role in Faḍlallāh's relationships with commoners and statesmen, as well as in his execution. That is why we have placed special emphasis on Faḍlallāh's ties with the 'ulamā' and sufi circles. We discuss how the 'ulamā' and sufis tried to disqualify the other flourishing rival groups in the period leading up to Faḍlallāh's execution.
\end{abstract}

Keywords: Faḍlallāh Astarābādī, Hurūfism, XV'th Century Mystisism.

\section{Fazlullah Hurufî ve Dünyası: İktidar, Din ve Sufilik}

\section{$\ddot{\mathbf{O} z}$}

Bu makale, Fazlullah Hurufî'nin Esterabad'dan ayrıldığı ilk gençlik çağlarından başlayarak Timur'un oğlu Miranşah'ın yönetimi altında idam edildiği (796/1394) döneme kadarki süreçte politik ve dini çevrelerle ilişkilerini detaylı bir şekilde incelemektedir. Fazlullah'ın idam edilmesinin nedenleri arasında onun batıl fikirleri, mesihçi hedefleri veya iktidara ulaşma gayreti gösterilmiştir. Çalışmamızda bunun gibi basmakalıp tezleri çürütmek için bazı ipuçları bulmaya çalıştık. Bu amaçla,

* Prof. Dr., Ankara University, Faculty of Languages History and Geography, Department of Turkish Language and Literature, Ankara/TURKEY fusluer@ankara.edu.tr ORCID: 0000-0001-5543-770X DOI: 10.37879/belleten.2021.463

Application date of article: 16.10.2018 - Approval date of article: 05.04.2021 
Fazlullah'ın devlet adamlarıyla ilişkilerinden hareketle iktidara ve iktidar olmaya karşı duruşunu ve bakışını belirlemeye çalıştık. Onun idamında devlet adamlarıyla ilişkileri yanında ulema ve mutasavvıflarla ilişkilerinin belirleyici rol oynadığını söyleyebiliriz. $\mathrm{Bu}$ nedenle ulema ve sufi çevrelerle ilişkilerini özellikle irdeledik. Fazlullah'ın idam edildiği dönemde ulema ve sufilerin, ortaya çıkan rakip grupları nasıl saf dışı bırakmaya çalıştıklarını göstermeye çalıştık.

Anahtar Kelimeler: Fazlullah Esterâbâdî, Hurufilik, XV. yüzyıl sufiliği.

\section{Travels and the Manifestations}

Faḍlallāh (740-796/1340-1394) leaves his hometown of Astarabad at the age of nineteen (759/1359) for the Kaba' ${ }^{1}$. Travelling on foot, Faḍlallāh visits Isfahan, the Ka'ba, Khwarazm, Semirom, Mashhad, Khwarazm, Yazd, Isfahan, and Tabriz. His second series of major travels after leaving Tabriz included Gawrud Castle, Gilan, Hazar Jarib in Mazandaran, Qadibagh in Astarabad, Damghan, Bastam, Sabzevar, Samarqand, Mashhad, Burujird, Isfahan, Baku, the Baku Islands, Shamakhi, and Alinjaq.

Faḍlallāh arrives in Tabriz at the age of thirty-five (775/1374). Including the almost twelve years spent in Tabriz, his early travels happened when he had almost achieved his spiritual ascent.

He embarked on his travels to achieve spirituality and to reach perfection; the first divine beneficence comes in Khwarazm and gifts him with the knowledge of dream interpretation². After Faḍlallāh settles in Tabriz, he goes into arba'een [a

1 The main modern sources on Faḍlallāh's early life are Hellmut Ritter, "Studien zur Geschichte der Islamischen Frömmigkeit: Die Anfange der Hurufisekte”, Oriens, no. 7, June 1954, pp. 1-54 trans. H. Mu’ayyad, Farhang-i İrān Zemīn, no. 10, 1341 H.sh., pp. 319-393; Ṣādiq Kiyā, Vāzhanāmayi Gurgān̄̄, Dānishgāh-i Tehrān, Tehran 1330 H.sh; Shahzad Bashir, Fazlallah Astarabadi and the Hurufis, Oneworld, Oxford 2005, Ya'qūb Āzhand, Hurufiyya dar Tārīkh, Ney, Tehran 1369 H.sh, 'Abdulbāqī Golpinarli, Hurüfilik Metinleri Katalogu, TTK, Ankara 1989, Orkhan Mir-Kasimov, Faḍlallāh Astarābādī, EIr, Orkhan Mir-Kasimov (ed.), Unity in diversity. Mysticism, messianism and the construction of religious authority in Islam, Brill, Leiden 2013, Fatih Usluer, Hurüflik; Ilk Elden Kaynaklarla Dogusundan Itibaren, Kabalci, Istanbul 2009.

2 The date of this event is given as 760 in the translation of $K h^{w} \bar{a} b-n \bar{a} m a$ and 765 in the original $K h^{w} \bar{a} b$-nāma. Nāfajī, on the other hand, sufficed with saying that he engaged in prayers until the ages $b \bar{\imath} s t u s \bar{\imath}$, i.e. twenty and thirty, and that only then was he gifted with the knowledge of dream interpretation. Firishteoghlu 'Abd al-Majīd, Tarjama-i Kh' āb-nāma in Usluer, Hâbnâmeler, p.

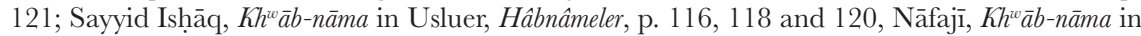
Usluer, Hâbnâmeler, p. 243 and 263. In the f. 406a marginal note of the Cambridge, E. 1.27 copy of Fāvidān-nāma-yi Kabīr, it is noted that Faḍlallāh was blessed with the gift of interpreting dreams 
forty-day retreat] on the tenth day of Sha'bān in 775 (2 February 1374) ${ }^{3}$. In the month of Ramaḍān in 775 (March 1374), he was blessed with the interpretation of Quranic Muqața'āt, disconnected letters, and of the secrets to the methods of sharīa, which refers only to Hurufism. Indeed, $K h^{w} \bar{a} b$-nāma confirms it to be the truths also explained in Faḍlallāh's Fāvidān-nāma, 'Arsh-nāma, and Mahabbat-nāma'.

Another date regarding Faḍlallāh's spiritual life is 788/1386. According to Kursī$n \bar{a} m a$, it was the year that he revealed the secrets of the Quran ${ }^{5}$. Kiyā recognises the discovery that took place on those two dates as the period when Faḍlallāh started to proselytise the 'new religion' in Tabriz'. However, we know well that Fạ̣lallāh attracted followers in each city he travelled to after he was gifted with dream interpretation in Khwarazm. So it is more appropriate to understand the "new religion" called by Kiyā as that Faḍlallāh was blessed with the gift to interpret divine speech in 775/1374 and that the sect was formed on the basis of letters.

At the beginning of one of the anonymous Hurufi manuscripts, it reads that the manifestation of wisdom on Faḍlallāh occurred in the year 788/1386 ${ }^{7}$. In another booklet, the same date was noted with Faḍlallāh's zuhūr u burūz (manifestation and appearance $)^{8}$. Kursi-nāma dates the 'penning of the Master Book' as 788/13869. Ritter defines the zuhūr u burüz of 788/1386 to be the discovery of the key of the Quran ${ }^{10}$. However, the discovery of the key of the Quran took place in 775/1374, Ritter probably meant the Secrets of the Quran.

Consequently, Faḍlallāh was first gifted with the ability to interpret dreams in Khwarazm (765/1363), and then the knowledge of the Quran and the hadith, the Muqaț̣a'āt in the Quran, the secrets to the methods of the shari'a, and the

\footnotetext{
in 765/1363. The year 772/1370-1 given by Gölpınarlı is not accurate ('Abdulbāqī Golpinarli, "Fạ̣l-Allah Hurūfi", El2, Vol. II, p. 733).

3 Sayyid Ishāà, Khw āb-nāma in Usluer, Hâbnâmeler, p. 176.

4 Sayyid Ishāà, Kh' āb-nāma in Usluer, Hâbnâmeler, p. 122.

5 'Alī al-A'lā, Kursī-nāma, Bibliotheque Nationale, Persan, No. 255, f. 76a; Millet Library, 'Alī Amīrī, Persian, No. 1035, f. 12b.

6 Șādiq Kiyā, ibid., p. 289.

7 Millet Library, 'Alī Amīrī, Persian, No. 269, f. la.

8 Millet Library, 'Alī Amīrī, Persian, No. 1052, f. 7a.

9 'Alī al-A'lā, Kursī-nāma, Millet Library, 'Alī Amīrī, Persian, No. 1035, f. 12b; Bibliotheque Nationale, Persan, No. 255, f. 76a.

10 Ritter, ibid., p. 22.
} 
reconnaissance of Prophet Muhammad's posts, truths, and secrets in Tabriz (775 Ramaḍān/March 1374).

Faḍlallāh's zuhūr u burūz which refers to his reveal the Secrets of the Quran was either in his last days in Tabriz or soon after he left (788/1386) for Gilan and Damghan. Kursī-nāma read that 'the Master Book has been penned' by referring to Jāvidān-näma (in 788/1386), sheds light on what we should understand from zuhür u burüz $z^{11}$. The fact that, in 787-8/1386, Faḍlallāh aimed at Fāvidān-nāma and told Mawlānā Hājī Muhammad Qummī, 'You'll have what's destined to salvage you in thirty years from now', and that after thirty years Muhammad Qummī took fävidān-nāma in his hands ${ }^{12}$.

When we take a look at all Faḍlallāh's travels, both before and after Tabriz, we see that he lived in every big city, such as Isfahan and Tabriz, for about 12 years. Though he passed several cities during his journey, it is clear that he spent more time in big cities.

The Hurufis explain that Faḍlallāh did not settle down in a certain location until Tabriz because he was irritated by the growing attention around him. Sayyid Ishāq notes that Faḍlallāh would retire into seclusion everywhere he lodged on the way back from his first visit to the $\mathrm{Ka}$ ba, and that he would leave and set off again when noticed by the locals ${ }^{13}$.

11 Chun zi Fadl asrār-i Kur'ān kashf gasht

Bud hïrat hạșad u hashtīd $u$ hasht (hafșad u haftād u hasht in Bibliotheque Nationale, Persan, No. 255, f. $76 \mathrm{a})$

Asl-i ìshān bud kard ān dah mazīd

$\dot{T} \bar{a}$ dalīl-i dīgar āyad z'ān badīd

Chun kitāb-i aș āmad dar qalam

Būd hïrat d̄àd bāz ez-vay du kam

Bīst u yak rā agar nihā $\bar{d} \bar{c}$ dar-shumār

Dād u t̄̄ bāshad k'ez-ū shod āshikār

'Alī al-A'lā, Kursì-nāma, Millet Library, 'Alī Amīrī, Persian, No. 1035, f. 12b; Bibliotheque Nationale, Persan, No. 255, f. 76 a.

The abjad i.e. numerical value of the 21 letters of which basmala consists is equal to 788. If we add to this sum the number of the 21 letters it is 809 . On the other hand, the abjad of the letters Dād and țī, is 809. So 788/1386 is the date of 'the Master Book has been penned'. And 809 is the date in which these ideas or Kursī-nāma in general revealed to him. As it was stated in the notes of Kurs̄̄-nāma in Millet Library, 'Alī Amīīì, Persian, No. 1035, f. 12b. For further interpretations cf. Səadat Şıxıyeva, "Hürufiliyin tarixi: ənənəviləşmiş təhriflər, unudulmuş gerçəkliklər", Metafizika (1) 2, 2018, pp. 68-69.

12 Sayyid Ishạā, Khw āb-nāma in Usluer, Hâbnâmeler, pp. 207-208.

13 Sayyid Ishāā, Khw āb-nāma in Usluer, Hâbnâmeler, p. 116 and 118. 
Thus, we see that Faḍlallāh was already drawing people's attention long before he was gifted with the ability to interpret dreams. Faḍlallāh gained a reputation in Khwarazm for interpreting dreams, but he was later irritated by the attention and left for Yazd and then for Isfahan and Tabriz for the same reason.

It might sound contradictory that someone like Faḍlallāh who did not cherish communal company would travel to more crowded and cosmopolitan places. Some might explain the strict asceticism (zuhd) that he maintained wherever he went and the sleepless nights that he spent crying and praying to restrain his corporal instincts ${ }^{14}$ as a pursuit that garners a reputation in society ${ }^{15}$. Others might claim that Faḍlallāh aimed to establish a better reputation by maintaining an ascetic lifestyle.

Though Faḍlallāh might well have thought that he would attract less attention in big cities, one question arises at this point: Did Faḍlallāh seek out a particular environment and audience, or did he really choose to abandon the cities because of the growing attention that might have led to problems? Indeed, Khw $\bar{a} b$-nāma does not include the name Tabriz, and refers to the city as dār al-amān [the House of Safety]. As detailed below, the dervishes in Tabriz felt more 'at peace' when statesmen started joining Faḍlallāh's talks. In conclusion, Tabriz, for Faḍlallāh, was quite a prolific city both for the manifestations and the knowledge bestowed upon him, and for disclosing his wisdom in educational and political circles.

\section{Mahdihood, Messiahhood}

The matter of Faḍlallāh's mahdihood leads to the thinking that he pursued political interests, which are also thought to have been why he changed locations and was executed. Therefore, the matter of Faḍlallāh's mahdihood deserves detailed attention.

In his works, Faḍlallāh quite implicatively predicates this issue in an ambiguous manner ${ }^{16}$. One might infer from his statements that he was the Messiah, or the Ādem-i Haqīīi, i.e. the Real Adam. After his death, some of his disciples made speeches recognising him as the Mahdi or Messiah. However, Faḍlallāh frequently stated that he was the possessor of the interpretation; in other words, the one who

14 Shahzad Bashir, ibid., p. 15.

15 Bashir, ibid., p. 22.

16 See: Fatih Usluer, Hurufilik., pp. 363-375. 
revealed the essential meaning of the Quran. There is no proof that he revealed his Mahdihood to other people he came across, though some of his disciples might have disclosed this secret to others. Let us emphasise this point: the $z u h \overline{\mathrm{u}} r u$ burūz mentioned above refers to the beginning of the penning of Favidāan-näma rather than Faḍlallāh's public claim to mahdihood.

Here is a brief introduction of Fā̃idān-nāma-yi Kabìr. Written by Faḍlallāh, the book mostly included Astarābādī dialect despite some parts being in Persian. The book, which was written during Faḍlallāh's troubled travels and migration that lasted for eight years after he left Tabriz, looks more like a draft of a book than a bound book for this very reason. The book was later edited by him or one of his disciples in modern Persian by removing repetitions and combining passages on the same subjects, and it is called Fā̄idān-nāma-yi Saghīr.

Fāvidān-nāma-yi Kabīr includes a section that piques the interest of researchers. This section is called Nawm-namma ${ }^{17}$, though it is not a separate book. In this section, Faḍlallāh writes about his dreams, sometimes with small notes referring to where and when he had them. The frequently abandoned sentences, word groups, as well as some post-predicate sentences tell us that Faḍlallāh took these notes not for the reader's benefit but for his own. As stated earlier, Fāvidān-nāma is very much like a draft of a book.

It is apparent that Faḍlallāh took heed of the dreams and the messages he wrote down in his book; otherwise he would not have recorded them. We will now look into the dreams he had in Tabriz and Sufian, a location that is 40 kilometres from Tabriz, and the notes he took about them.

In the beginning of the month of Șafar in 786 (April 1384), Faḍlallāh had a dream in Sufian. In it, he saw 'Omar Sulțān̄̄ being murdered and his men attacking him as a result and Shaykh $\mathrm{Kh}^{\mathrm{w}}$ āja ultimately killing him. Dervīsh Tawakkul tells the saddened Hurufi dervishes to mind their own business. In his dream, Faḍlallāh wants to tell them not to worry, that Jesus will come back and explain what is going on, but he stops himself, thinking that they would find it insensible. 'Omar's men ask why the dervishes told Amīr Shams that 'Omar was unwary. Amīr Shams confirms what Façlallāh had said: 'Yā Mawlānā'. One of 'Omar's men kills Faḍlallāh's murderer. 'Ubayd goes up to 'Omar's men who killed Faḍlallāh,

17 See: Orkhan Mir-Kasimov, 'Le 'Journal des Rêves' de Fadlullah Astarabadi: Edition et Traduction annotée”, Studia Iranica XXXVIII (2009), pp. 249-304. 
followed by Dervīsh Musāfir and 'Abd al-Rahīm, to fight them. Dervīsh Kamāl al-Dīn stands by Faḍlallāh, praying for him to come back to life as he is sure that Faḍlallāh will. After he wakes up, as he starts to think about what happened and the soldiers of the Pharaoh who perished in the Nile, someone shows up with a hide for Faḍlallāh. This reminds Faḍlallāh of Hagar's sacrifice on the stone ${ }^{18}$.

The name 'Omar Sulțānī in the dream during Șafar 786/April 1384, suggests Amīr ${ }^{\prime} \mathrm{Omar}^{19}$ who captured the Sultani Castle in 785/1383. Sources lack information on Shaykh Khwāja who is not to be confused with $\mathrm{Kh}^{w}$ āja Shaykh, one of the viziers to Sultān Uvays. There was a Shaykh Hājī who travelled from Sultani to Tabriz with Maḥmūd Khalkhālī in the year 793/1390 and captured the city of Tabriz from the reign of Altūn' ${ }^{20}$ 'Abd al-Rahīm, 'Ubayd, Dervīsh Tawakkul, and Dervīsh Kamāl al-Dīn were Hurufi dervishes.

In Sufian, Faḍlallāh has another dream in which he is abstemious with food and drink $^{21}$. In another dream in Tabriz, he sees drums being played in his honour and for festivities in Mashhad. The same night he also sees Jesus' disciples. In the dream he has in Tabriz during Ramaḍan, Mawlānā Majd al-Dīn, who has returned from Anatolia and enthroned 'Alī on a great post, stands to his right. One of his dreams dated to Jumāda I 776 (October 1374) is thought to have occurred in Tabriz, and though the location is not specified, its date suggests that he was in Tabriz. In this dream, Faḍlallāh sees three counsels given to the son of a sultan. These counsels are make your ground red, want a lot, and be generous. He later realises that this person is the Prophet David. Therefore, Faḍlallāh interprets these counsels to David as you should shed blood, you should have many soldiers, and you should forgive generously. At that moment, he sees his right hand in an open position. He thinks that his dervishes will agree with his interpretation when he tells them of his dream.

His next dream occurs in the month of Dhū al-Hijja and we think it occurred in the same year. In this dream, Faḍlallāh sees his clothing: clean, white, overly washed, and discarded. It is his own clothing but he sees it as the Mahdi's. He knows that he is the Mahdi. In a dream from 783, he sees idols coming to life in his

18 Faḍlallāh Astarābādī, Jāoidān-nāma, Millet Library, 'Alī Amīrī, Persian, No. 1046, ff. 298a-298b.

19 Faṣị̣ Khwāeì, Mujmal-i Faṣīhī. Ed. Sayyid Muhsin Nājī Naṣr-ābādī, Esāṭīr, Tehran, 1386 H.sh., Vol. III, p. 984.

20 Khwāfi, ibid., p. 996.

21 Faḍlallāh Astarābādī, fā̃vidān-nāma, f. 300a. 
house (in Tabriz) and the Prophet Muhammad coming there thanks to his prayers and destroying the idols. Another dream on Shawwāl 9, 786/2 December 1384, is also thought to have occurred in Tabriz due to its date. In this dream, Faḍlallāh sees a river, which is flowing through a vineyard, suddenly flood as strong as the Amu Darya. As he worries that his family will drown in the flood, a voice comes out of the water as if breaking the soil apart. Faḍlallāh goes to the vineyard where he sees that some things have been burnt down, and Khwāja Bāyazīd asks Faḍlallāh whether it is the time of mercy or grace, addressing him as 'O Amīr'. Faḍlallāh thinks that he has been summoned and sees a blackness in the river and follows it. He recites the verse of 'My Lord, let me land at a blessed landing place, and You are the best to accommodate [us]' Al-Mu'minūn/29, and greets 'Alī b. Abī Ṭālib. 'Alī says, 'Al-Salāmu 'alaykum, brother, give me your hand, hold my hand.' He pledges with Faḍlallāh and let's go of his hand. The beginning of that pledge is, 'You have embraced the servants of God as mine.' When 'Alī addresses him, he thinks that 'Alī used the word maja, i.e. father or ancestor. He asks him, 'Did you call me that?' 'Alī answers, 'Don't you know you're the Adam?' Faḍlallāh replies, 'Yes, I do ${ }^{22}$.'

The messages of these dreams are quite assertive. However, it is debatable if an accurate reality analysis could be based on them. Some researchers who are studying Faḍlallāh's dream interpretations have inferred that he had political ambitions and intended to fight to gain power ${ }^{23}$. There is no historical evidence that indicates that Faḍlallāh had any intent to bear arms or made an attempt to rebel or seize power.

Even the period chronicles bearing information about Faḍlallāh (d. 796/1394) mention no claims brought by Faḍlallāh on being the Mahdi. These sources mention the following reasons for his execution: his growing number of followers; abandoning the fard, i.e. the religious duties; tateel [negating the apparent meaning of the divine attributes of Allah] and ibăha [considering Islamic law, i.e. the sharīa, not to be obligatory]; spoiling the faith of the community ${ }^{24}$; the thought that humans are just like letters and the groundless belief in superstitions; and inviting Timur into his ${ }^{25}$ advent.

22 Faḍlallāh Astarābādī, Jā̄idān-nāma, ff. 299b, 300a, 300b, 301a, 301b.

23 Ritter, ibid., p. 24.

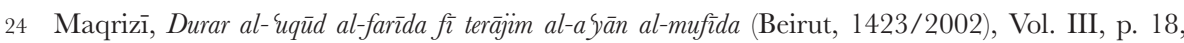
Sakhawī, Al-daw' al-lāmi'a li-ahl al-qarn al-tāsi á, Dār al-ghayb al-Islāmī, Beirut 1412/1992), Vol. VI, p. 174.

25 Ibn Ḥājar al- 'Asqalān̄̄, Inbā' al-ghumr bi-abnā' al-'umr, Iḥyā al-Turāth, Cairo, 1415/1994, fas. II, p. 219; Sakhawī, ibid., Vol. VI, p. 173. 
Thus, the things that led to Faḍlallāh's execution were neither his Mahdihood nor his desire for power. We believe that what should be done at this point is to deeply study the network of relationships of the $14^{\text {th }}$ century mystic within political, scholarly, and sufi circles. These relationships could shed light on his alleged power intentions, as well as on the reasons behind his travels and execution.

\section{His Relations with the 'ulamā' and Other Sufis}

There have been conflicts and intolerance between sufi circles and the madrasa 'ulamā' throughout history. It is quite difficult to assert that Faḍlallāh was a madrasa 'ulamā'-opposing shaykh. We know that some of his followers, including Nāfajī, Mawlānā Majd al-Dīn Jūrī, Mawlānā Maḥmūd Naīmīi, Abū al-Ḥasan, and Mawlānā Majd al-Dīn, were also studying at the madrasa whilst attending Faḍlallāh's assemblies. Nāfajī states in Isfahan: 'From all over, scholars, prominent statesmen comprised of sayyids, amirs, and viziers, as well as Qādīs, commandersin-chief, and the gentry would attend to his assemblies. You could not find a place to sit if you had not already secured one early in the morning. The truths of the Quran and hadith were discussed in his assemblies ${ }^{26}$.'

The most important figure to attend Faḍlallāh's talks in Isfahan was Khwāja Șadr al-Dīn Turke of the Iraqi 'ulamā', or as Nāfajī puts it, afdal-i ulemā-i 'aș, hakīm-i mustabsir-i süfì nihād, șăhib-i ma ārif, șăhib-i akhlāq-i mardiyye. In a dream ${ }^{27}$, Turke sees the Prophet Muhammad performing his ablutions as he pours water for the Prophet. Suddenly, some water from Șadr al-Dīn's mouth drops on Muhammad's hand. Khwāja Șadr al-Dīn feels uncomfortable and ashamed. Muhammad looks at him and smiles. Khwāja Șadr al-Dīn tells Faḍlallāh about this dream. According to Faḍlallāh's interpretation, he wants to travel to the Ka'ba to stay and write a book on wisdom and Islamic law, a book that applies fiqh matters to philosophy. His pouring water for the Prophet and dripping water from his mouth onto the

26 Nāfajī, Khَ̄ āb-nāma in Usluer, Hâbnâmeler, p. 244.

27 There is another report on the same dream but it is only found in the translation and it belongs to Mawlānā Șadr al-Dīn Turke. According to this version, Khwāja Șadr al-Dīn has a dream in which someone kisses the hand of the Prophet Muhammad, and some water from his mouth drops onto the Prophet's hand. Khwāja Șadr al-Dīn is saddened by this. Faḍlallāh interprets this dream just as he does in the other report, and even mentions the title of the book that Khwa a ja Șadr al-Dīn thought of writing: Jāmic $i$ Máqūl ve Manqūl. See: Firishteoghlu, Tarjama-i Kh ${ }^{w} \bar{a} b-n \bar{a} m a$ in Usluer, Hâbnâmeler, p. 226. In Nāfajī's report, however, as Șadr al-Dīn Turke kisses the hand of the Prophet Muhammad, some saliva from his mouth is transferred to the Prophet's hand. See: Nāfajī, Khì āb-nāma in Usluer, Hâbnâmeler, pp. 249-250. 
Prophet's hand indicate his idea of writing the book. Muhammad's smile indicates that his sharica cannot be correlated with philosophy (the wisdom of the wise). Fạ̣lallāh tells Ṣadr al-Dīn that the fact that he has only thought about this and has not told anyone about it was why he had this dream. Faḍlallāh asks what kind of dream he would have had if his idea had come to fruition. Șadr al-Dīn stands up after he hears the interpretation, kisses Faḍlallāh's hand, and tells him that he has abandoned the idea ${ }^{28}$.

In a dream mentioned in Fāvidān-näma, Faḍlallāh sees himself at the door of Mawlānā Șadr al-Dīn. He holds a shiny sword in his hand. The surface of the sword has an inscription, written with liquid gold and in beautiful calligraphy by an astrologer based on his knowledge of the stars, and it reads that there will be a chaos that will be followed by the emergence of a person called Faḍl of Astarabad $^{29}$.

Faḍlallāh has another dream in which he sees the Ka'ba levitating. He sees the Kaba in the model of the thirty-two. The trees around the Kaba are also thirty-two in number and they move. He sees murdered people, fallen trees, and Mawlānā Ṣadr al-Dīn nearby. It seems like he is moving it from its leaf. Ka'ba's neighbours ask: 'Oh, the borderless Ka'ba, where would you like to land?'30

In another report recorded in Nāfajī's $K h^{w} \bar{a} b$-nāma, a dream by Af̣̂lal al-Dīn Turke, Khwāja Șadr al-Dīn's father, is told and interpreted. Nāfajī addresses him as 'the $\mathrm{Kh}^{w} \overline{\mathrm{a} j a}$ of the servants, the savant, the ascetic, the wise, the mulla Khwāja Afdal al-Dīn Turke.' Af̣̣al al-Dīn arrives in Faḍlallāh's assembly and tells him that he saw Allah in his dream, and that Allah told him, 'Afdal , I am building a dome for you, and I don't want you to worship me if I don't finish it.' Faḍlallāh tells Afḍal al-Dīn that it is a very important dream but interpreting it would be inappropriate and that all the dervishes are included in its interpretation so it would be akin to showing off. At Afḍal al-Dīn's insistence, Faḍlallāh interprets the dream. He asks if Afḍal al-Dīn was thinking of asking for a felt hat that was made by a poor man. Afdal al-Dīn stands up and says 'Yes' as he cries. 'That was what I thought, please have them bring the hat.' They brought the hat and the turban, which he kisses and puts on his head, and wraps the turban around $\mathrm{it}^{31}$.

Sayyid Isḥāq, Kh' āb-nāma in Usluer, Hâbnâmeler, p. 130.

29

Faḍlallāh Astarābādī, Jā̃idān-nāma, f. 301a.

30

Faḍlallāh Astarābādī, fāvidān-nāma, ff. 30 la-301b.

Nāfaj̄̄, Khw āb-nāma in Usluer, Hâbnâmeler, p. 250. 
It is clear that these dream interpretations happened before Timur conquered Isfahan in 789/1387 and the Turke family were sent away to Samarqand. The people who were sent away included Khwāja Șadr al-Dīn, his father Af̣̣al al-Dīn, and his brother Șāin al-Dīn ${ }^{32}$.

Șā’in al-Dīn is known to be among the questioned following the Hurufis' attempt to assassinate Shāhrukh in 830/1427. Tortured in prison, Șāin al-Dīn was later sent into exile ${ }^{33}$.

Another figure from Isfahan is Zayn al-Dīn Rajāyī. Along with his followers, he attended the assemblies held by Faḍlallāh. Quoting a dream of Zayn al-Dīn - one of the shaykhs of the period - and its interpretation, Nāfajī reports that Faḍlallāh's unerring dream interpretation brought him much fame and that Zayn al-Dīn kept telling him about this dream and its interpretation until the day he died ${ }^{34}$.

After he left Tabriz, Faḍlallāh came into contact with sufis who thought positively of him. Sayyid Șā’in al-Dīn Bayhaqī, a famous sayyid, was one of them. Sayyid Șā’in al-Dīn Bayhaqī participated in one of Faḍlallāh's assemblies in Sabzevar and asked: 'Someone sees someone else reciting the Quran in his dream, can we know who has the dream and recites the Quran?' Faḍlallāh interpreted this as it was Șāin al-Dīn who had the dream, and the one who recited the Quran was Dervīsh Rukn al-Dīn, one of the shaykhs of the period ${ }^{35}$. Șāinn al-Dīn asked Faḍlallāh what surah he recited in his dream, to which Faḍlallāh answered the Surah al-Jumu'ah. Faḍlallāh answered several of his questions, and in the last one, asked him to strip his clothes of pride and become a dervish. He rejected the request. Years later, the

32 See: Melvin-Koushki Matthew S., The Quest for a Universal Science: The Occult Philosophy of Sā in alDīn Turka Isfahan! (1369-1432) and Intellectual Millenarianism in Early Temürid Iran, PhD Dissertation, Yale University 2012, pp. 39-41. For works in detail please see: Melvin-Koushki, ibid., pp. 80-158.

33 Chahārdah Risāla-yi Fārs̄̄ az-Șāin al-Dīn 'Alī b. Muhammad Turke-yi Isfahān̄̄, ed. S. A. M. Bihbahānī and S. I. Dībājī, Taqī Sharīf Riḍā̄̄, Tehran 1351 H.sh., p. 205-206. See also: Ilker Evrim Binbaş, "The Anatomy of a Regicide Attempt: Shāhrukh, the Hurufis, and the Timurid Intellectuals in 830/1426-27", FRAS, XXIII (2013), pp. 391-428 and Beatrice Manz, Power, Politics and Religion in Timurid Iran, Cambridge University Press, Cambridge 2007, p. 42.

34 Nāfajī, Khَ̄āb-nāma in Usluer, Hâbnâmeler, p. 249.

35 Dervīsh Rukn al-Dīn is one of the followers of Shaykh Hasan Jūrī. He took over the city of Sabzevar from Khwāja 'Alī Mu'ayyad in the year 778/1376, but in 780/1378, Khwāja 'Alī Mu'ayyad, with the help of Amīr Valī, besieged the city and defeated Dervīsh Rukn al-Dīn. Dervīsh Rukn al-Dīn's date of death is not known. However, if this interpretation took place in Sabzevar while Dervīsh Rukn al-Dīn was still alive as noted in the dream, we can deduce that he did not die in that war. 
person who collects these reports encounters Sayyid Sā̄in al-Dīn. He expresses his regret for not listening to Faḍlallāh, and says that he lost his fortune soon after that incident ${ }^{36}$.

Șāin al-Dīn Bayhaqī also had Faḍlallāh interpret one of his dreams. According to Fạ̣lallāh's interpretation, Șāin al-Dīn bought a pre-pubescent female slave. When Șāin al-Dīn wanted to make love to her, she escaped. Hurt, he also moved away. Faḍlallāh tells him to respect puberty and age restrictions. Ṣāin al-Dīn accepts the interpretation ${ }^{37}$. Sayyid Șāin al-Dīn Bayhaqī's rejection of being a dervish might be his dissatisfaction with the above interpretation.

Faḍlallāh's relationship with the 'ulamā' and the sufis who made it to his assemblies in Isfahan and other cities were not always this positive. According to the Hurufis, even though the most common reason why Faḍlallāh kept changing locations is said to have been the growing fondness of the commoners, the negative impressions and rumours about him must also have had an effect. The debates with the 'ulamā', particularly the debates that were lost by the 'ulamā', or Faḍlallāh exposing some of the weaknesses of the 'ulamā', might have also contributed to the situation.

In Yazd, where he went after he was gifted with the ability to interpret dreams in Khwarazm, the 'ulamā' fabricated rumours about Faḍlallāh. One day, while Sayyid Husām al-Dīn Astarābādī was in Faḍlallāh’s assembly, a crow began crowing suddenly. Sayyid Husām al-Dīn asked Faḍlallāh if he could tell what the crow was saying. Faḍlallāh answered: 'It is telling me that you gossiped about me with the congregation in so-and-so caravanserai last night ${ }^{38}$.'

Faḍlallāh travelled to Isfahan after Yazd. In Isfahan, Maḥmūd Rashānānī, 'one of the venerable men of the period who produced words on philosophy', attended Faḍlallāh's assemblies. They had a discussion over whether a man keeps his consciousness after he dies. Mạ̣mūd Rashānānī tried to prove through rational evidence that the soul cannot have consciousness after the body rots. Faḍlallāh disproves him by presenting the Quran verses and hadith as evidence. Mawlānā Mahmūd asks him to come up with rational evidence, and not to solely rely on verses and hadith. Faḍlallāh tells him then he should not stick to the words of Plato and Aristoteles. Later, Faḍlallāh tells Mawlānā Mạ̣mūd that he had a dream

36 Sayyid Ishāq, Kh $h^{w} \bar{a} b$-nāma in Usluer, Hâbnâmeler, p. 142.

37 Sayyid Ishāq, Khwa āb-nāma in Usluer, Hâbnâmeler, p. 142.

38 Firishteoghlu, Tarjama-i Khw āb-nāma in Usluer, Hâbnâmeler, p. 227. 
earlier that he interpreted, but that he must now listen to another interpretation of it. He tells him where he kept his money during the reformation in Isfahan, the amount, and type. Mawlānā Mạ̣mūd tells him that he knows that he had the ability to transcend to the al-Ghāìb. Faḍlallāh tells him that philosophers says that God does not know the juz iy ät, and the scholars of sharīa, He is cognizant of the parts and the whole (juz iy ät and kulliyāt). He tells him that his treasure is from the juz iy ät. If a servant of God knows of the juz iy $\bar{a} t$, then it is more than plausible that God also knows it and that it is He who teaches it to His servant.

Later, Faḍllallāh tells Mawlānā Mạ̣mūd what he was doing and thinking one evening, and Mạ̣mūd confirms that he is correct. Faḍlallāh asks him whether knowing these things is binding, to which Mawlānā Maḥmūd answers that it should not necessarily be known. Faḍlallāh says that it is fard and sunna for you and me and all the Muslims to know of the consciousness of their souls, and the beginning and the end. We must know whether the soul will have consciousness after the body rots. Mawlānā Mạ̣mūd also confirms this. 'The thing that should not necessarily be known was taught to me by God as I am subject to Rasūl alAllah. Then, wouldn't I have been told about the thing that I need to know, the thing that is necessary for my salvation?'39

In his Fāvidān-nāma-yi Kab̄̄r, Faḍlallāh writes about his discussion with Mawlānā Mạ̣mūd Rashānānī on how to find pleasure without a body in a world other than this, and how one can dream, know, feel frightened, hear, etc ${ }^{40}$. This confirms the above-mentioned report.

We should mention Sayyid Hāshim, the last 'ulamā' who had Faḍlallāh interpret his dream in Isfahan. Though he is referred to as Sayyid Hāshim Golestenā-i Iṣfahān̄̄ (and Sayyid Hāshim Golestānī in some translations) in Kh'āa-nāma, the accurate translation is Golestāne. There are many members of the 'ulamā' with the name of 'Golestāne-i Ișfahānī', and the Golestāne is one of the most famous sayyid families of Isfahan ${ }^{41}$. Sayyid Hāshim relays his own dream and its interpretation in this report. In his dream, while seated with a man, two sets of women's clothing are brought out. Sayyid Hāshim wants to wear one of the outfits, but fails. Faḍlallāh interprets this and notes that those two people have agreed to

39 Sayyid Isḥāq, Khwāa-nāma in Usluer, Hâbnâmeler, pp. 102-108.

40 Faḍlallāh Astarābādī, Jāoidān-nāma, f. 296a.

41 See: Mīr Sayyid Ḥujjat Muvahhịid Abțahī, Rīshahā ve Jilvehā-yi Tashayyu've Havza-i Tlmiyya-i Isfahān der tụl- $i$ Tàrīkh, Daftar-i Tablīghāt al-Mahdī, Isfahan, 1376 H.sh., Vol. I, p. 483. 
meet somewhere to drink wine, making a deal that one will get someone drunk for a purpose. According to the interpretation, both of them get drunk and they fail to reach their goal. Sayyid Hāshim confirms the interpretation to be true ${ }^{42}$.

A similar event also takes place in Tabriz that would have irritated Ibn-i Faḍlallāh 'Ubaydī of the 'ulamā's3. He visits Faḍlallāh Astarābādī and tells him that in his dream he held a bowl of poison in his hands and drank it. Faḍlallāh does not want to interpret the dream, saying that it is too late. The mulla insists that he interpret it and Faḍlallāh asks everyone else to leave. Only the famous Sayyid Amīr Aḥmad, also known as Imām Iṣfahānī, who is a stranger to the city, Sayyid 'Ivaḍ, and Khª̄āja Hasan Kāshī remain. Nāfajī quotes this part of the report from Amīr Aḥmad: 'Faḍlallāh turns to Ibn-i Faḍlallāh 'Ubaydī and tells him that he has recently taken a prostitute to his home for his pleasure, held her close, and kissed her. The prostitute hit him on the face.' The dreamer denies it and Faḍlallāh tells him that the prostitute has a mole on her face and describes her veil, but 'Ubaydī still denies it. Faḍlallāh turns to Sayyid Amīr Ahmad and tells him to take someone with him and go to so-and-so's house where four prostitutes live. He tells him to ask the one with a mole on her face and with dresses as he described where and with whom she was on a specified night. When Amīr Aḥmad stands up, 'Ubaydī tells him to sit down, and says that it is all true, and confirms the interpretation ${ }^{44}$.

One interpretation of the dream by one of the followers of Mawlānā Imām, who we could not identify though he was most probably a local shaykh in Tabriz, had the potential to irritate the sufis, as well as the 'ulamā'. A Tabrizì follower of Mawlānā Imām attended Faḍlallāh's assembly and told him that he had a dream. Faḍlallāh tells him that he did not have a dream, but the follower insists, saying that he saw a flying crow with a piece of liver in its mouth, and the liver fell out of its mouth into a well and disappeared. Faḍlallāh tells him that he will interpret the dream for his sake, even though he did not have that dream. According to Shaykh Safi al-Din Ardabili in the archives of the Centre of Religious Foundations and Charity in Iran. The letter, dated to Sha'bān, 785, reveals that his first name is 'Abd al-Malik. He signed the letter as the qādī using the name 'Abd al-Malīk b. Fadlullah 'Ubaydī (Ibn-i 'Ubaydī). http://

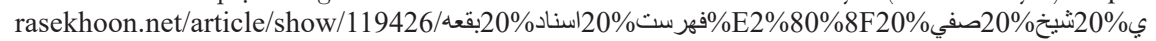

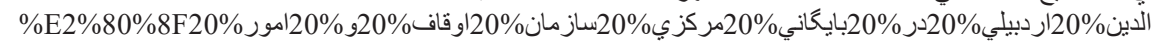
/خيريه

Nāfaj̄̄, Khw⿳亠̄⿲丿-nāma in Usluer, Hâbnâmeler, pp. 255-256.

Belleten, Ağustos 2021, Cilt: 85/Sayı: 303; 463-505 
the interpretation, the dreamer was given twenty tenges of gold by an old woman in the Maidan neighbourhood of Tabriz to later give to her daughter. However, when the daughter, now an adult, came to claim her money, the Tabrizi follower denied that he was ever asked to give her the money. Hearing this interpretation, the Tabrizī asks Faḍlallāh about the details of the gold. Faḍlallāh tells him about the line on it and where he hid it. The Tabrizī confirms the interpretation after Faḍlallāh says that he will have someone go get the gold if he continues to deny $\mathrm{it}^{45}$.

A woman from Tabriz sees in her dream that the moon comes down to the earth and people reach to catch it but they cannot touch it. Faḍlallāh asks her if she tried to touch it too, to which the woman says no. Faḍlallāh interprets the dream as the people of Tabriz who are trying to catch him but they are not strong enough. According to narrator, those who were turned away reported to the judges that many people from the upper and lower classes participated in Faḍlallāh's assembly and that those who attended were hiding guns. Such reports made the judges suspicious of him, and one night the dervishes were surrounded by soldiers. The dervishes saw in the morning that they had been besieged and sent word to Faḍlallāh, who tells them not to worry as it was what the woman had seen in her dream. The soldiers find nothing but the personal belongings of the dervishes. The investigation proves that the allegations were false ${ }^{46}$.

This must surely be the best example of how some of the 'ulamā' and the sufis secretly conducted propaganda against Faḍlallāh and his followers in the community and within political circles. It is a well-known fact that when the 'ulamā' and the sufis wanted to destroy someone or a movement that was gaining respect in the eyes of the people and the government, they used the arguments of doctrines and faith and fabricated that the movement intended to overthrow the government and seize power. In this context, what bothered some of the 'ulamā' and the sufis most must have been Faḍlallāh's political ties. This tells us that Faḍlallāh conducted good relations within political circles and gained recognition until this particular boiling point, and that is what we should prioritise. Propounding Faḍlallāh's relationship with those in political circles will also show whether he intended to 'seize power'.

45 Sayyid Ishāā, Khw āb-nāma in Usluer, Hâbnâmeler, p. 212 and 214.

46 Sayyid Ishāq, Khwāb-nāma, in Usluer, Hâbnâmeler, p. 190 and 192. 


\section{Relations with Political Gircles}

Faḍlallāh's relationships with the political circles of the period was possibly motivated by the need to confirm their legitimacy of politicians, and to provide the necessary trust and support in order to continue their activities. Indeed, it was noted by the Hurufis that the dervishes enjoyed peace and freedom thanks to the visits of Sultān Uvays (reign: 757-776/1356-1374) and his viziers to Faḍlallāh's lodge and their care ${ }^{47}$.

Bashir notes that Faḍlallāh was interested in social and political matters as seen from his interpretations during his time in Tabriz ${ }^{48}$. He also notes that he was particularly open to making contacts within the upper classes, which explains why he agreed to marry the vizier's daughter in Tabriz ${ }^{49}$. However, it is known that Faḍlallāh was distant with government officials except in religious matters. The best example of this is him becoming a son-in-law to Khwāja Bāyazīd, a vizier to Sultān Uvays.

One day, Khwāja Bāyazīd Damghānī’s wife ${ }^{50}$ called Mawlānā Kamāl al-Dīn Hāshimī, one of Faḍlallāh's trainees and later one of his successors, and told him that she wants to talk to Faḍlallāh even if it has to be behind a curtain. Faḍlallāh welcomes her. She asks Faḍlallāh to take her daughter as a servant in the lodge, i.e. as his wife. She says that this will hopefully be the means of their salvation in the afterlife. Although Faḍlallāh first says that it is a huge imposition, the woman insists, and Faḍlallāh tells her that he will only say yes if his conditions are met.

The conditions that Faḍlallāh laid out for this marriage were quite harsh. The harshness of these conditions makes the claim that Faḍlallāh wanted to make political contacts for his political ambitions controversial. In brief, the conditions were as follows:

She will bring nothing from her house. Her clothing, food, and all other needs will be met only by the earnings of the dervishes. She will never leave the zāwiya or visit anyone in their home. She will sleep on a straw mat and felt pillows, and she will wear cotton dresses. After the assembly is dismissed and Faḍlallāh moves

47 Sayyid Ishāq, Kh'⿳亠丷冖 -nāma in Usluer, Hâbnâmeler, p. 122.

48 Bashir, ibid., p. 22.

49 Bashir, ibid., p. 22.

50 She and her spouse from the Būkardiyān tribe (or the Pūkardiyān, a tribe in Astarabad) became Faḍlallāh's followers. 
into the cell, she will not allow nobody in. She will not disturb Faḍlallāh when he is busy with his spirituality at night. She will follow the programmes and activities of the dervishes ${ }^{51}$.

The daughter of the vizier Bāyazịd Damghānī, whose name is not given in the texts out of respect or for moral reasons and who is only referred to as the Hadrat $i$ 'alliya, agrees to the conditions. If Faḍlallāh arrived in Tabriz in the year 775, as stated above, he must have been at least 35 years old when he got married.

The fact that Nāfajī, just like his shaykh Faḍlallāh, was sceptical about the money gained from tutoring the children of statesmen like amirs and viziers, thinking that such statesmen would not be careful with their earnings from a religious perspective $^{52}$, was another example of how the Hurufis saw the elite in the government. The followers' sensitivity to such matters was certainly influenced by Faḍlallāh's lifestyle. Faḍlallāh only ate food that was prepared by the dervishes, and he forbade his wife, the vizier Bāyazīd Damghānīs daughter, from bringing any food from her house ${ }^{53}$.

There is no data indicating that Faḍlallāh appealed or paid special respect to statesmen simply to earn their sympathy. Sulțān Uvays and his viziers, Amīr Bisțām, Sabzevar governor Khwāja Jamāl al-Dīn, and Amīr Eygu Timur all chose to attend Faḍlallāh's assemblies.

\section{The Jalairids}

Faḍlallāh's relationship with Sulțān Uvays of the Jalairid Sultanate is the first example that we know of regarding his relations within top-level political circles. Faḍlallāh moved into the Valī-i Dolaq zawiya in Tabriz. Several top-level statesmen frequented Faḍlallāh's assemblies that took place in this zawiya. Among them were important names such as Sulțān Uvays (reign: 757-776/1356-1374), his vizier Amīr Zakariyyā, and Khwāja Shaykh ${ }^{54}$.

We know that Faḍlallāh arrived in Tabriz in 775/1374 and ended his arba in observance in the month of Ramaḍān (March 1374). Since Sultān Uvays died on Jumāda I 2, 776/9 October 1374, we can infer that Sultān Uvays was in contact with Faḍlallāh in the last year of his life.

51 Sayyid Ishāà, Khw āb-nāma in Usluer, Hâbnâmeler, p. 122.

52 Nāfajī, Kh $h^{w} \bar{a} b$-nāma in Usluer, Hâbnâmeler, p. 257.

53 Sayyid Ishāq, Khَ'āb-nāma in Usluer, Hâbnâmeler, p. 180 and 182.

54 Sayyid Ishāà, Khwāb-nāma in Usluer, Hâbnâmeler, p. 122. 
Sulțān Uvays and Faḍlallāh met for the first time when a Christian scholar came to Tabriz and challenged all Muslim scholars that he would convert to Islam if anyone could provide him with proof in the Quran that Prophet Muhammad is superior to Jesus. When the news spread of his arrival, some of the scholars wanted him to be exiled from the city. One of the Christian scholar's conditions was that the debate would have to take place before the Sultan. When Sultān Uvays heard the news, he summoned the 'ulamā'. The 'ulamā', i.e. the scholars, brought Quranic evidence that stood for Muhammad's virtues, and the Christian scholar brought Biblical evidence of Jesus' virtues. The Christian scholar had knowledge of Arabic and tafsir, and he could not be disproven. The 'ulamā' said that asking questions and giving answers to the Christian scholar before the Sultan would be sacrilegious. The Sultan said that giving up on him would indicate weakness and inadequacy.

Mawlānā Majd al-Dīn, who was present at the assembly, said to the Sultan: 'The 'ulamā' here cannot disprove him. If you like, let them take him to the Possessor of Interpretation (Faḍlallāh). The Possessor of Interpretation is also gifted with the ability to interpret the verses and parables revealed in the Bible. Faḍlallāh can answer his questions through the Bible and disprove him.' Sultān Uvays ordered the Christian scholar to be taken to Faḍlallāh's assembly. As a result, the Christian scholar, who was disproven, asked to visit the zawiya the following day to convert to Islam $^{55}$.

It is difficult to infer how close the relationship between Sultān Uvays and Faḍlallāh was after this incident. Sultān Uvays died about seven months after Faḍlallāh arrived in Tabriz. In one of the dreams from Khwarazm, Faḍlallāh sees himself as was seated on a throne in Astarabad where he opened a letter that he thought was written by Sultān Uvays to Amīr Valī̄ ${ }^{-56}$.

When Amīr Valī took Astarabad again (757/1356) from Sarbadaran following Toga Timur's death, Sultān Uvays came to power in the Jalairid Sultanate. Before Fac̣lallāh arrived in Tabriz, in the year 772/1370, Amīr Valī and Sultān Uvays fought a war that resulted in the city of Ray being annexed by the Jalairids ${ }^{58}$.

55 Sayyid Isḥāq, Kh $h^{w} \bar{a} b$-nāma in Usluer, Hâbnâmeler, p. 198, 200 and 202.

56 Faḍlallāh Astarābādī, fāòidān-nāma, f. 297a.

57 John M. Smith, History of the Sarbadar Dynasty: 1336-1381 A.D. and its sources, Mouton, The Hague Paris, 1970, pp. 142-144.

58 Khwāndamīr, Tārn̄kh-i Habīb al-Siyar, Kitābfurshi-i Khayyām, Tehran 1362 H.sh., Vol. III, p. 241. 
Since Faḍlallāh was in Khwarazm in 765/1363, this dream must have occurred before the war. In this dream Faḍlallāh referred to Amīr Valī as the fourteenth man next to him beside Allah and the eleven honoured men. Mutual relations seem to have improved when (in 779/1377) Amìr Valī married his daughter off to Sultān Husayn, the son of Sulțān Uvays, whom he had made peace with ${ }^{59}$.

When we take a look at the other statesmen that Faḍlallāh came into contact with during the reign of Sultān Uvays, an important name stands out: Amīr Zakariyyā. Amīr Zakariyyā was appointed as vizier during the reign of Shaikh Hasan (Hasan Buzurg), Sulțān Uvays' father in the year 736/133560. Amīr Zakariyyā also served as a vizier to Sulțān Ḥusayn (1374-1382), the successor of Sultān Uvays ${ }^{61}$.

In his dream, Sulțān Uvays' vizier Amīr Zakariyyā loses all his teeth. He visits Faḍlallāh to tell him about his dream, and Faḍlallāh tells him that it is about his past. Amīr Zakariyyā wanted to know what it meant. Faḍlallāh walked into his khalvat-khāna, one of its doors open to the zawiya and another to his harem, and invited Amīr Zakariyyā in. Sometime later, Amīr Zakariyyā leaves and kisses the threshold of the house. Faḍlallāh's family and inner circle later earn about his interpretation: Before Amīr Zakariyyā became the vizier, he was entrusted with thirty-two large and valuable pearls by someone who then went on a campaign. That person died in battle, and Amīr Zakariyyā achieved the vizier post and became one of the sultan's lieutenants. When the heir of the late person came to claim the pearls, Amīr Zakariyyā did not bestow favours on him. The heir died without leaving any survivors. Faḍlallāh told Amīr Zakariyyā to relieve the burden by giving the pearls as alms. Amīr Zakariyyā accepted this interpretation and asked forgiveness from $\operatorname{God}^{62}$.

Another important figure within the close circle of Sultān Uvays who became a dervish to Faḍlallāh is Amīr 'Alī Damghānī. Amīr 'Alī is interesting because he was the father of Ḥasan Damghānī (reign: 762-766) ${ }^{63}$, also known as the Pahlivān, the eighth amir to the Sarbadaran ${ }^{64}$. It is known that he was the governor of

59 Khwāfi, ibid., Vol. III, p. 976.

60 According to Khwāndamīr, in the year 737/1336.

61 Khwāfi, ibid., Vol. III, p. 915; Khwāandamīr, ibid., Vol. III, p. 227-246.

62 Sayyid Ishāà, Khَ̄āb-nāma in Usluer, Hâbnâmeler, p. 188 and 190.

63 Davlatshāh, Tadhkirat al-Shu'arā, ed. E. Brown, Brill, Leiden 1900, pp. 285-286.

64 There is no mention of Hasan Damghān̄̄'s son or father in historical sources. In Mahram-nāma, Amīr 'Alī Damghānī is said to be Hasan Damghānī's father (in the Gurgan dialect يَِّر حسن دامغانى). 
Khorasan. In his Mahram-nāma, Sayyid Ishāq writes about a dream by Sayyid Tāj al-Dīnn ${ }^{65}$, one of the trainees in Faḍlallāh's assembly. In his dream, Sayyid Tāj al-Dīn sees himself as 'Alī b. Abī Ṭālib. People happened to know him as 'Alī as well and many of them are his subjects. When Tāj al-Dīn tells the assembly about his dream, everybody sees Faḍlallāh change and get angry. Faḍlallāh does not interpret the dream. When the assembly is dismissed, Faḍlallāh moves into his khalvat-khāna and calls Mawlānā Kamāl al-Dīn Hāshimī and asks him: 'Did you hear the dream of that miserable man?' When Hāshimī asks who he was talking about, he replies that it was Sayyid Tāj al-Dīn. He states that Tāj al-Dīn takes himself for 'Alī, and that his vision is superstitious. He then goes on to say that he was just like the man who told Kamāl al-Dīn Hāshimī about his superstitious visions. Hāshimī realises that the man who is like Sayyid Tāj al-Dīn is Amīr 'Alī Damghān̄i. One day, Amīr 'Alī Damghānī tells Hāshimī that he has been thinking of marrying one of Faḍlallāh's daughters. Hāshimī remarks that whoever said such a thing should abandon that harmful idea ${ }^{66}$. That is what Faḍlallāh means by the superstitious idea. It is likely seen as being superstitious due to his desire to marry Faḍlallāh's daughter in spite of his advanced age.

It should be emphasised that Amīr 'Alī Damghānī, who was enrolled in Faḍlallāh's circle, was a Sarbadari who served Sultān Uvays. It is important as it shows the flexibility of the relationships and transitions among the smaller states in $15^{\text {th }}$ century Iran.

It is also probable that Mubārak Shāh Tirmizī, mentioned in the translation of $K h^{w} \bar{a} b$-nāma, is Amīr Mubārak Shāh, one of Sulțān Uvays' amirss ${ }^{67}$. Mubārak Shāh Tirmizī sees a yellow scorpion in his dream and hits it with a tree branch. The scorpion wraps around the edge of the branch, and he has to hit the branch on the ground several times in order to kill the scorpion. He hears a voice, from God, saying that he has been freed of the demon. He tells Façlallāh about his dream and Faḍlallāh interprets it as follows: Tirmizì has an impudent slave who indulges in debauchery. He eventually cut off one of his body parts, albeit against

\footnotetext{
We recognise this information from Mahram-nāma as being accurate and acknowledge that Amīr 'Alī Damghānī was Ḥasan Damghānī's father. Likely due to a misunderstanding, Āzhand and Ritter claim that he is Ḥasan Damghānī’s son. Ya'qūb Āzhand, ibid., p. 8; Ritter, ibid., p. 40.

65 In the extant copy of Mahram-nāma, Sayyid Tāj al-Dīn is referred to as Kahnā-i Bayhaqī.

66 Sayyid Ishāa, Mahram-nāma, Millet Library, 'Alī Amīrī, Persian, No. 1031, ff. 39a-39b.

67 Khwāfì, ibid., Vol. II, p. 961.
} 
the Sharīa a, and fires him. Mubārak Shāh Tirmizī answers that he had a slave with blond hair and blue eyes who caused him a lot of trouble, so he cut off his ear and fired him. Faḍlallāh says that the voice he heard in the dream means that he does not have to apply the rule of qisas, i.e. retributive justice according to the sharî $\mathrm{a}^{68}$. After Sultān Husayn took over the city of Tabriz from the Muzaffarids, he was killed by his brother Ahmad on Ṣafar 1 1, 784/4 May 1382. Despite Sulțān Ahmad's enthronement, his brother Sulțān Bāyazīd took over Tabriz in the same year. The city was conquered by ‘'̄èlil Aqa soon after, but Sulțān Aḥmad recaptured Tabriz one year later ${ }^{69}$.

We do not have any proof that indicates a direct relationship between Sultān Ahmad and Faḍlallāh. With that being said, we do have a report that mentions a relationship between Faḍlallāh and Jallād Khan Rūmī, the brother of Sultānn Ahmad's wife ${ }^{70}$.

\section{The Muzaffarids}

After his death (Jumāda I 2, 776/9 October 1374), Sultān Uvays was succeeded by Sultāan Husayn Jalairid. Soon after Muzaffarid Shāh Shujā‘ took Tabriz from Sultān Husayn (777/1375), he had to return to Isfahan in the winter when fitna broke out. Sultānn Husayn recaptures Tabriz as a result, and Shāh Shujā̄ conquers Tabriz for a second time in $783^{71}$.

Faḍlallāh makes a dream interpretation during the time that Tabriz is taken by the Muzaffarids. We would like to quote an event that shows what stance the 'ulamā' took when the administration changed. Mawlānā Majd al-Dīn and Mawlānā Maḥmūd Na'īmi ${ }^{72}$, two of Faḍlallāh's closest followers, also studied at the madrasa

68 Firishteoghlu, Tarjama-i Khw āb-nāma in Usluer, Hâbnâmeler, p. 229. Islamic scholars agree that one who cuts off a slave's body part is not subject to the qisas. Some scholars claim that the slave will then be free in such a situation, based on a practice by the Prophet Muhammad. See: Ibn Māja, Diyat 29.

69 Khwāfi, ibid., Vol. III, pp. 974-989.

70 The translation says that it occurred in Baghdad. The Persian version of $K h^{w} \bar{a} b-n \bar{a} m a$, however, does not mention Baghdad at all. Furthermore, no other report in $K h^{w} \bar{a} b$-nāma implies that Faḍlallāh was in Baghdad. It is also possible that Jallād Khan had the dream in Baghdad but told it to Faḍlallāh in Tabriz or somewhere else. Sayyid Ishāā, Khwāab-nāma in Usluer, Hâbnâmeler, p. 196 and 198.

71 Khwāfi, ibid., Vol. III, pp. 974-989.

72 In the Turkish translation of $K h^{w} \bar{a} b-n \bar{a} m a$, the names are noted as Mawlānā Majd al-Dīn Khūrī 
with Mawlānā 'Izz al-Dīn Halvānī’3 . Mawlānā Majd al-Dīn and Mawlānā Mahmūd mentioned the interpretations they have heard directly from Faḍlallāh to their teacher, Mawlānā 'Izz al-Dīn Ḥalvānī, at the madrasa. As a madrasa teacher, Halvānī believes that it has something to do with shaykhs allowing the public to learn from their foresight. However, the students said that this was not confined to mere foresight, but is knowledge from God's level. In response, Halvānī tells them about a dream he had and asks them to have Faḍlallāh interpret it.

In his dream, Halvānī sees the Prophet Muhammad. He walks to greet him and Muhammad puts his spread fingers on his face. The two students tell this dream to Faḍlallāh. According to Faḍlallāh's interpretation, when Halvānī freed himself from the administration of Sultān Uvays' sons, he wrote a treatise for Shāh Shujāe in Tabriz. Inclusive of several fields of science, the treatise, or the risāla, had five items on fiqh. When Shāh Shujā̄ arrived in Tabriz, Halvānī decided not to present it to Shāh Shujāác. He thought that he would be ashamed of dedicating such a work to Shāh Shujā̄ if Sulțān Uvays' sons recaptured Tabriz. He therefore removed Shāh Shujā's name from the preface of his work. The risāla, which he had yet to show anyone, included nothing useful but the five matters on fiqh. Faḍlallāh interprets that this is what was meant when the Prophet Muhammad put his five fingers, spread out, on his face. When Mawlānā 'Izz al-Dīn Ḥalvānī listens to the interpretation from his students, he says that those facts, which are not known by anyone else, are true ${ }^{74}$. Gölpınarl, Āzhand and Mir-Kasimov misconstrue this report and claim that Faḍlallāh wrote a fiqh book for Shāh Shujā̄ ${ }^{-c 7}$.

Nāfajī reports another dream interpretation that is said to belong to Amīr Farrukh Gunbadī. However, we believe that it belongs to Amìr Farrukh Kabandī ${ }^{76}$, one of the amirs who accompanied Shāh Shujāe when he took Tabriz from Sulțān Husayn in 777/1375. Häfiz-i Kharābātī notes that Amīr Farrukh used to serve

and Mawlānā Mahmūd Bahhāth. (Firishteoghlu, Tarjama-i Khwāb-nāma in Usluer, Hâbnâmeler, p. 131) However, the name Mawlānā Maḥmūd Baḥhāth is inaccurate as Mawlānā Maḥmūd Bahḥāth was an Isfahan-based scholar who produced works on wisdom, while the Mawlānā Maḥmūd who attended Faḍlallāh's talks in Tabriz and would later become one of his caliphs is a madrasa student.

73 Sayyid Isḥāq, Khª̄ân-nāma in Usluer, Hâbnâmeler, p. 130. In translation: Halvāȳī.

74 Sayyid Isḥāq, Khwāb-nāma in Usluer, Hâbnâmeler, p. 130 and 132.

75 'Abdulbāqī Golpinarli, "Faḍl-Allah Ḥurūfì", EI2 Vol. II, p. 733; Āzhand, ibid., p. 16; MirKasimov, Words of Power, p. 11.

76 Mạ̣mūd Kutubī, Tārìkh-i āl-i Muzaffar, Amīr Kabīr, Tehran 1364 H.sh., pp. 103-104. 
the Jalairids but then chose to follow Shāh Shujā̄ Muzaffarī, and fought against Sultān Husayn along with Shāh Shujā̄'. Following Shāh Shujā's death, he served Sultān Ahmad and fought alongside him against Timur to defend Baghdad. Amīr Farrukh, to whom Ḥāfiz-i Shīrāzī wrote a couple of ghazals, died in 803/140077.

In his dream, Amīr Farrukh sees four dragons standing before him. According to Faḍlallāh's interpretation, Amīr Farrukh had a ring weighing 1.5 shekel that had been lost for four years, but he would have it again in fourteen days. Amïr Farrukh says that he had forgotten about the ring, however, fourteen days later, while passing through the bazaar, he lingers in a gold dealer's shop. At that moment, someone shows up and takes the ring out of a pile of cottons that are for sale. Amīr Farrukh recognises his ring and buys it right away ${ }^{78}$.

Faḍlallāh's relationship with the Muzaffarids, who did not stay in Tabriz for very long, is limited to these incidents. However, chaos would continue in Tabriz, as the Mongols and Timurids would soon invade the city, a process that Faḍlallāh witnesses first-hand.

\section{Timurids and Faḍlallāh}

In the year 787/1385-6, the Khan of the Golden Horde, Toqtamish, attacked and pillaged Tabriz ${ }^{79}$. In that time, Faḍlallāh sees Toqtamish Khan in a dream. We believe that this might have happened after Toqtamish Khan captured Sarai in $779 / 1377$. He thinks about getting a girl from him - a girl who would give him a son - but then he remembers that the people of Sarai (Toqtamish's capital) are lazy ${ }^{80}$.

The Jalairids and Timurids are pitted against each other in the same year. Sultān Ahmmad assigns Amīr Valī and Amīr Sunțay to besiege Soltani Castle, which is under 'Ādil Aqa's dominion. In response, Timur sends his soldiers stationed at the Khorasan border under the command of Qara Bisțām, Amīr Luṭf-Allah, Amīr Jāgir, and his son Amīr Bisțām to help Amīr 'Ādil. 'Ādil Aqa fences off the besieged area before the amirs arrive and these amirs spend the winter of 788/1386 in Ray.

77 Rukn al-Dīn Humāyūn Farrukh, Hāâziz-i Kharābātī, Asāṭī, Tehran 1361 H.sh., Vol. V, pp. 38653866.

78 Nāfajī, Khº āb-nāma in Usluer, Hâbnâmeler, p. 252.

79 Muḥammad Yūsuf Vāleh Iṣfahānī Qazvīnī, Khuld-i Berīn: Sections 6-7, ed. Mīr Hāshim Muhaddith, Amīr Kabīr, Tehran 2001, pp 114 and 140.

80 Faụlallāh Astarābādī, fā̄idān-nāma, f. 295b. 
When spring comes, they defeat Sultān Aḥmad's soldiers and assign two amirs among them to capture Amīr Valī, who is with Mạ̣mūd Khalkhālī. They capture Amīr Valī, behead him on the road, and bring his head to the amirs. They take Amīr Valī's head and dispatches it to Mīrānshāh in Nishapur on Ṣafar 788/April 1386. The amirs leave for Tabriz from there. Gathering with Timur, they conquer Tabriz together. Timur gives Tabriz to Amīr Muḥammad Sulțān Shāh. During that war, Sultān Aḥmad abandons Tabriz and flees to Baghdad ${ }^{81}$.

$K h^{w} \bar{a} b$-nāma reports that one of Faḍlallāh's trainees had a dream as they were travelling to Gilan ${ }^{82}$ from Tabriz. In his interpretation of the dream, Faḍlallāh says that when they arrive at Gawrud Castle ${ }^{83}$, there will be an assembly by Amīr Bistām, the governor of the place, and that some of the members of the 'ulamā' and the public will be present at the assembly. Indeed, when they arrive, they are welcomed by Amīr Bistām and the locals. In the assembly, Faḍlallāh exposes a charlatan scholar. Amīr Bisțām wants to punish the scholar but Faḍlallāh asks him not to and instead tells him to keep those who deviated from the law of Muhammad away from his assemblies. Amīr Bisțām follows Faḍlallāh’s warning. Sayyid Ishāq reports that he heard about the incident from Amīr Bisțām himself ${ }^{84}$.

Since $K h^{w} \bar{a} b$-nāma notes that Amīr Bisțām, knowing that Faḍlallāh is on his way to Gawrud Castle, greets Faḍlallāh, we can say that Amīr Bisṭām knew Faḍlallāh. Another finding that supports this is a story told by Amīr Bistām himself.

Amīr Bisțām says: 'My father was alive when Faḍlallāh was in Tabriz. My father and I were suspicious of his assemblies. One day, my friends and I thought of

81 Hāfiz-i Abrū, Zubdat al-Tavārīkh, ed. Sayyid Javādī, Vazārat-i Farhang u Irshād-i Islāmī, Tehran 1380 H.sh., Vol. II, pp. 648-651; Khª̄āì, ibid., Vol. III, pp. 974-989.

82 The name of the place that is noted as Jilan in $K h^{w} \bar{a} b-n \bar{a} m a$ is modern Gilan. Jilan is a village in Shahrud. It is known that Faḍlallāh passed from Damghan to travel to Sabzevar from Gilan (Sayyid Ishāā, Khwāab-nāma in Usluer, Hâbnâmeler, p. 166), whereas Jilan is not located on the route from Damghan to Sabzevar. In addition, Kh'āb-nāma notes that Shāhrukh sent Sayyid 'Abd alHayy to 'Lahijan, a town in Jilan' (Sayyid Ishāq, Khwāb-nāma in Usluer, Hâbnâmeler, p. 134 and 136). Since Lahijan is a subdivision of Gilan, the Jilan that is mentioned in the work must be modern Gilan.

83 The manuscript refers to Castle Gawrud with a different spelling. There is Kawerd (a village in Sari) and Gawerd (a township in Hazar Jarib, Mazandaran). However, we have no information of whether there was a castle in those small settlements. With that being said, there is the Gawrud Castle, whose name is quite similar. With the probability of an error having occurred during the copying process, we think that it is the Gawrud Castle that is referred to in this work.

84 Sayyid Ishāa, Khwāb-nāma in Usluer, Hâbnâmeler, p. 138 and 140; Firishteoghlu, Tarjama-i Kh ${ }^{w} \bar{a} b^{-}$ nāma in Usluer, Hâbnâmeler, p. 139 and 141. 
organizing a drinking party in the countryside but we did not have time for it. I had a dream in which I was thrown down from somewhere up high. In the morning I went to Faḍlallāh's assembly and told him about my dream. Faḍlallāh told me about the plan that I made with my friends and said that I had the dream because of that plan ${ }^{85}$.'

We can say that Faḍlallāh, Amīr Bisțām, and Amīr Jāgir first came together at the conquest of Tabriz in 788/1386, and then at Gawrud Castle. Amīr Bistām opposed and fought against Timur's son, 'Omar Bahādur, in the year 808/1405. When he conquered the Soltani Castle in 811/1408, he was awarded by Qara Yūsuf and was made governor of $\operatorname{Iraq}^{86}$. He fought against Qara Yūsuf in Soltani in 815/1412, and Qara Yūsuf took Amīr Bistāam's brother Amīrzada Muhammad Manșūr as a prisoner in 816/1413. In 817/1414, he pledged allegiance and obedience to Shāhrukh ${ }^{87}$.

This network of relationships shows that soldiers like Amīr Bisțām could change positions in politics, an approach that did not apply to their relations with religious people like Faḍlallāh. In other words, the Amīr Bistâam example weakens the opinion that there was strong animosity between the Timurid Dynasty and the Hurufis/Hurufism sympathisers.

Faḍlallāh's next stop after Gilan was Hazar Gari, known as Hazar Jarib today, in Mazandaran. In Fāvidān-nāma, Faḍlallāh notes a dream that he had in this town. While he is in Hazar Gari, Dervīsh Kamāl al-Dīn has gone to Samarqand. In the dream, Dervīsh Kamāl al-Dīn tells Faḍlallāh that if he travelled to another land (which Faḍlallāh thinks is Iraq ${ }^{88}$ ), he would be opposed by no one, and all the doors would be open to him. People would go to him and would not oppress him $^{89}$. Faḍlallāh has another dream while in Hazar Gari, from which he infers that blood will be shed ${ }^{90}$.

Faḍlallāh, after Hazar Gari, on his way to Damghan passes by Qadibagh where

85 Sayyid Ishāā, Khwa āb-nāma in Usluer, Hâbnâmeler, p. 140 and 142.

86 Khwāfì, ibid., Vol. III, pp. 1025, 1044, 1062, 1063.

87 Rūmlu, Aḥsan al-Tavārīkh, ed. 'Abd al-Ḥusayn Navā'ī, Asāṭīr, Tehran 1384 H.sh., Vol. I, p. 213.

88 We do not know whether Faḍlallāh went to Iraq, but he mentions Baghdad in his dreams. See: Faḍlallāh Astarābādī, Fāùidān-nāma, ff. 298a, 300b, 301b.

89 Faụlallāh Astarābādī, Jāoidān-nāma, f. 299a.

90 Faụlallāh Astarābādī, Jā̄idān-nāma, f. 299b. 
he had dream in 8 Rajab 789/25 July 138791. In Damghan, however, Jamshīd Ghālī, the governor of Damghan (noted only as Jamshīd in the translation), does not allow Faḍlallāh's family to leave Damghan. We know that Faḍlallāh wanted to take his family to Samarqand. Someone in the town rebukes him, saying how Faḍlallāh, who knows everything, does not know that the governor of Damghan would not allow his family to leave the town. Faḍlallāh explains his dreams and experiences to the man, and says that he knew about it just like he knew everything else, but that he cannot go against destiny ${ }^{92}$.

Jamshīd Ghālī, inaccurately spelled by a copier, is actually Jamshīd Qarīn (d. 805/1402), the governor of Damghan appointed by Timur in $790 / 1388^{93}$. This means that Faḍlallāh was in Damghan in 790 when Jamshīd was appointed as governor.

Another report claims that Faḍlallāh was also arrested in Damghan. In this incident, which perhaps took place when Faḍlallāh's family was not allowed to leave by Jamshīd Qarīn, Faḍlallāh and his three companions were imprisoned in the Damghan castle by someone called Kaljandar under the command of "Mārānshāh 'aleyhi la'na" (Amīrzāda Mīrānshāh in the translation). One day, a black crow lands on the bastions and crows three times. Faḍlallāh says that it is a bizarre crow, bringing bizarre news. His companions ask what news it has brought, and Faḍlallāh tells them that some time ago he saw in his dream magicians bringing the Holy Spirit from the sky down to the earth. Their magic was accompanied by a black crow. The Holy Spirit then turned and burnt the magicians with fire. He says that it was the black crow he had seen, and it means that they will leave this place in three days.

Three days passed before a decree was issued by Amīr Timur to set them free. Amìr Timur said that they were imprisoned without his knowledge, and he orders the execution of Kaljandar who imprisoned them. However, Faḍlallāh says that Kaljandar did not do so of his own volition and asks for mercy. Amīr Bozorg and Faḍlallāh meet in the vicinity of Bistam, and Haḍrat-i Amīr Bozorg shows him the utmost respect and esteem ${ }^{94}$.

Faḍlallāh Astarābādī, fā̄idān-nāma, f. 301b.

92 Sayyid Ishāq, Kh $h^{w} \bar{a} b$-nāma in Usluer, Hâbnâmeler, p. 210.

93 Khw̄āndamīr, ibid., Vol. III, p. 442.

94 Sayyid Ishāq, Khwāa-nāma in Usluer, Hâbnâmeler, p. 193. 
This story noted in $K h^{w} \bar{a} b-n \bar{a} m a$ is the first instance of the relationship between Mīrānshāh and Faḍlallāh. Mīrānshāh acted as the governor of Khorasan from 782/1380-1 to 795/1393 when he became the governor of western Iran. This incident must have occurred during Mīrānshāh's governorship of Khorasan. Despite Mīrānshāh's imprisonment of Faḍlallāh, his father set him free, which perhaps aroused a feeling of revenge in Mīrānshāh. Indeed, he would go to every effort to challenge Faḍlallāh the next time they met.

We could not identify Kaljandar, but the name of Amīr Bozorg is noted as Amīr Zayrak in two translation copies. Together with Amīr 'Omar, an amir called Amīr Zayrak was referred to legal authorities with the accusation of committing betrayal or acting jealously in a war waged among the amirs on Dhū al-Qa'da 808/August 1387 ${ }^{95}$. Amīr Bozorg is noted as Amīr Bozorg Mīr Timur in the translation ${ }^{96}$.

Timur goes on a long campaign in 788/1386, starting in Azerbaijan. He first captures Tabriz, followed by Nakhchivan and Georgia. He spends the winter in Qarabagh. The following year, he returns to Georgia, and besieges the castles of Alinjaq and Van to the south. From there, he continues to Isfahan and conquers it, and sends Amīr Eygu Timur off to Shiraz. He then goes to Shiraz and conquers it too, and returns in 790/1388 after completing his campaign ${ }^{97}$. We learn that Faḍlallāh travelled to Bistam after he was released from prison in Damghan from reports that state that he met Amīr Bozorg there and that Amīr Eygu Timur had Faḍlallāh interpret one of his dreams in Bistam.

Based on Khwāja Fakhr al-Dīn Bayhaqī’s report, Amīr Bozorg's army was stationed in Bistam at that time, and when they returned from Azerbaijan, Amīr Eygu (or Lengu, as it is written in some translations) entered Faḍlallāh's assembly and told him about his dream. In his dream, Amīr Eygu Timur, who is close to Amīr Bozorg, i.e. Amīr Timur, holds a bunch of black grapes in his hands. He eats seventeen of the grapes and gives the rest to one of his servants. In his interpretation, Faḍlallāh says that Amīr Eygu was given an Indian female slave whom he gave away to one of his servants after he had sex with her seventeen times. Amīr Eygu Timur stands up, kisses Faḍlallāh's hand, and confirms the interpretation ${ }^{98}$.

95 See Khwāfi, ibid., Vol. III, p. 1027.

96 The name Amīr Bozorg is used as a reference again from Timur, for example, in Sā̄in al-Dīn Turke's Chahārdah Risāla-yi Fārsī..., p. 170.

97 Khwāfi, ibid., Vol. III, pp. 989-992.

98 Sayyid Ishāq, Khw āb-nāma in Usluer, Hâbnâmeler, p. 146. 
Amīr Kamāl al-Dīn reports a dream about Amīrzada Muḥammad Qandahārī and its interpretation by Faḍlallāh. Since Qandahārī is the son of Jehāngīr Mīrzā who is the son of Timur, it is possible that Amīrzāda is Pīr Muhammad. We think that he took the name Qandahārī as he was posted to rule the region of Qandahār in 794/139299. Considering that the name Qandahārī might have been added by Sayyid Ishāq, it is possible that the meeting of Pīr Muhammad b. Jehāngīr (d. 809/1407) and Faḍlallāh took place after this date, but this is not certain. Indeed, we do not know when and where the incident took place.

In his dream, Amīrzāda Muḥammad notices grape vines with colourful grapes as he is walking. He wants to eat a black grape and puts it in his mouth and then takes it out. In his interpretation, Faḍlallāh tells him that he saw women washing clothes by the creek and that he took a liking to a brunette woman. In this context, Amīrzāda Muhammad summoned his servant to bring the woman to him. He wanted to make love to her but he quit after she told him 'to stay away from her for God's sake.' Amīrzāda confirmed the accuracy of the interpretation ${ }^{100}$.

Starting in Tabriz, Faḍlallāh passed through Gilan, Damghan, and Bistam to finally arrive in Sabzevar. He lodges in the Jow-furush inn in Sabzevar. Hearing about Faḍlallāh's arrival, Fakhr al-Dīn Qazvīnī takes Qāḍicha Hajī and Khª̄ja Jamāl al-Dīn, the governor of Sabzevar, with him and visits Faḍlallāh. In his dream, Khwāja Jamāl al-Dīn sees himself helping sayyids and passengers. Faḍlallāh interprets that Jamāl al-Dīn thought of doing something good for charity during a communion when Fakhr al-Dīn Qazvīnī was there. Indeed, Fakhr al-Dīn Qazvīnī heard $\mathrm{Kh}^{\mathrm{w}}$ āja Jamāl al-Dīn mention in a communion that he would like to coat the outer face of Imām Reḍā's dome with silver ${ }^{101}$.

We understand from another dream and its interpretation that the Sabzevar governor, Khwāja Jamāl al-Dīn, visited Faḍlallāh more than once. In this report, Khwāja Jamāl al-Dīn (Khª̄ja Kamāl al-Dīn in the translations) is said to be the nephew of 'Alī Mu'ayyad, the last amir of the Sarbadars ${ }^{102}$. In his dream, Khwāja Jamāl al-Dīn sees himself catching pigeons with his uncle, 'Alī Mu'ayyad. They

99 H.R. Roemer, "Temür in Iran”, in The Cambridge History of Iran, ed. P. Jackson, L. Lockhart, Cambridge University Press, Cambridge 1997, Vol. VI, p. 70.

100 Sayyid Ishāq, Khwāb-nāma in Usluer, Hâbnâmeler, p. 212.

101 Sayyid Ishāq, Kh $h^{w} \bar{a} b$-nāma in Usluer, Hâbnâmeler, p. 136.

102 There is no other report or information on Shaykh Hasan Shakhbānī (Shaykh Sajātī or Shaykh Sabahātī in the translations). 
plucked the wings and feathers of the birds and skewered them to make kebabs. However, the pigeons grew wings again and flew away. Faḍlallāh does not want to interpret this dream. Khwāja Jamāl al-Dīn tells him about another dream: 'I saw a mansion with windows, and there was a candle inside. A woman in the mansion entertained me. I wanted to blow out the candle so that nobody could see us through the windows. When I put out the candle, two more candles were lit. When I tried to put out those two candles, the mansion was filled with candles.' Faḍlallāh tells him that the dream was not about him either. Later, one of Hasan Jüriyya's dervishes comes along. Faḍlallāh says that Khwāja Jamāl al-Dīn's dreams were about Shaykh Hasan's circle, and that he will try to push them out of Khorasan entirely because of a disagreement between them but that he will fail. According to narrator's explanation, fifteen years after this interpretation, Khwāja Jamāl alDīn would exile any Jüriyya dervish on sight, but they would all come back in less than a year. Thus, their disagreement turned into something good ${ }^{103}$.

Another person referred to as the ruler of Sabzevar is Khwāja Faḍlallāh. His dream and its interpretation are jointly reported by Sayyid Fakhr al-Dīn Qazvīnī and Mawlānā Shadīd al-Dīn Jūrī (Mawlānā Sadīd al-Dīn, and Sayyid al-Dīn in translated copies). In his dream, Khwāja Faḍlallāh sees a pumpkin brought to him. When he cracks it open, he sees that it has gone bad. Faḍlallāh interprets that he will have a son who will fall ill at birth but will soon be healthy again. $\mathrm{Kh}^{w}$ āja Faḍlallāh says that his wife is pregnant, and as he walks out of the assembly, one of his servants comes to tell him that his wife has given birth to a boy ${ }^{104}$.

Faḍlallāh went to Sabzevar in the early 790s. At the end of the dream interpretation regarding Khwāja Jamāl al-Dīn, it was noted that he exiled the Jūrī dervishes for fifteen years after the interpretation. This coincides with the reign of Khwāja 'Imād al-Dīn Mas'ūd. We are forced to accept that Khwāja Jamāl al-Dīn, whom we could not identify, is possibly from Khª̄ja 'Imād al-Dīn Mas'ūd's family.

103 Sayyid Isḥāq, Khwa āb-nāma in Usluer, Hâbnâmeler, p. 154. Bashir links this interpretation to the Shayhiyya leader Dervīsh Rukn al-Dīn's expulsion from Sabzevar in 1375 and his return with a victory one year later and says that Faḍlallāh was in Sabzevar fifteen years before, i.e. in about 761/1360. Bashir, ibid., p. 14. However, Faḍlallāh was gifted with dream interpretation in 765/1363 in Khwarazm. Therefore, the one who expels the Jüriyya (Shayhiyya) dervishes from the city was Khwāja Jamāl al-Dīn, and this incident is more about the exile of the dervishes than Dervīsh Rukn al-Dīn's defeat in war.

104 Sayyid Ishāā, Khwāa-nāma in Usluer, Hâbnâmeler, p. 144. 
'Alī Mu'ayyad, together with Dervīsh-i 'Azīz Majdī - one of the Jūrī dervishesends Hasan Damghānı̄'s ruling and takes the helm of the Sarbadarans (766/13645). The first thing that he did was to kill Dervīsh 'Azìz, who opposed him for having Hasan Damghānī killed. He had Shaykh Hasan Jūrī and his leader Shaykh Khalīfa's tombs used as public restrooms. In close contact with Timur, 'Alī Mu'ayyad gave Khorasan to Timur and pledged allegiance to him ${ }^{105}$. After 'Alī Mu'ayyad's death in 788/1386, Timur appoints 'Alī Mu’ayyad's nephew, Khwāja 'Imād al-Dīn Mas'ūd, as the governor of Sabzevar. Khwāja 'Imād al-Dīn governed the city until he was killed at the conquest of Sabzevar by the amirs of Timur. After that, Amīr Sayyid Khwāja b. Shaykh 'Alī Bahādur was appointed to rule the region of Khorasan $^{106}$.

In historical sources, we could not find the names Khwāja Fac̣lallāh or Khwāja Jamāl al-Dīn among the governors and judges of Sabzevar from the time Faḍlallāh was gifted with dream interpretation until his death. We believe that these men were family members of 'Alī Mu'ayyad.

$K h^{w} \bar{a} b$-nāma notes that when fitna broke out in Khorasan, the region of the Sarbadaran, a man called Aq Malik Fīrūzkūhī went to Isfahan to have Faḍlallāh interpret his dream. That man was also a relative of 'Alī Mu'ayyad. In his dream, Aq Malik Fīrūzkūhī sees 400 dried human heads come down from the sky and gather in front of him. Faḍlallāh interprets that he took a vow to hang a candle of 400 shekels of gold at Imām Reḍā's grave in Mashhad but he did not fulfil this vow even though it was in his power to do so. His punishment in the spiritual world was 400 human heads, and if he went through with his vow, 400 men would pledge service to him and ask for his forgiveness from $\operatorname{God}^{107}$.

The name Aq Melik Fīrūzkūhī, is spelled in Khَّāb-nāma as Aq Mulūk (Aqa Mulūk in the translations) Fīrūzkūhī. Amīr Aq Melik, who was also known as Amīr Shāhī Sabzevārī and used the alias Shāhī in his poetry and was a calligrapher, painter, and musician, was the teacher of 'Abd al-Raḥmān Jāmī. He was Khwāja 'Alī Mu'ayyad's nephew ${ }^{108}$.

105 Davlatshāh, ibid., pp. 286-287.

$106 \mathrm{Kh}^{\mathrm{w}}$ āfi, ibid., Vol. III, pp. 989, 1020-1021.

107 Sayyid Ishāq, Khwāb-nāma in Usluer, Hâbnâmeler, p. 150.

108 Muhammad Riḍā Nuṣayrī, Asar-i Āferīnān, Anjuman-i Āṣār u Mafākhir-i Farhangī, Tehran 1384 H.sh., Vol. I, p. 299. 
Another report confirming that Faḍlallāh was in Sabzevar in 791/1388-9 is about Mawlānā Zayn al-Dīn Ābūbakr Taybādī. Naṣr-Allah (Naṣr in the translation) Sabzevārī notes that one day Faḍlallāh said in an assembly that a walī, Mawlānā Zayn al-Dīn Ābūbakr Taybādī (in the copies spelled as Mawlānā Zayn Ābūbakr Tabāyādī, Nābātrī, Nābāhāà̄e, and Tāyāhāeīi), had died in Khorasan. The people in the assembly recorded the date. A long time after this, the people coming from Khorasan confirmed what Faḍlallāh had said ${ }^{109}$. Mawlānā Zayn al-Dīn was a famous shaykh, and Timur respected him. We know that Mawlānā Zayn al-Dīn Ābūbakr Taybādī died at the end of Muharram, 791/1388-9110.

Fạ̣lallāh continues to travel after Sabzevar and reaches Samarqand. According to Sayyid Qāsim Sarābī’s report, Faḍlallāh settles near the bazaar in Samarqand. Timur hears about Faḍlallāh's settlement in Samarqand and one morning calls Amīr Eygu Timur (his real name is Amīr Hạj̄̄ Muhammad Amīr Eygu Timur and he died in 793/1391 ${ }^{111}$, a council amir who was one of the strong-willed followers and assembly-goers of Faḍlallāh, to go to his master and tell him that Timur had a dream in which he saw the entire earth covered with blinding smoke. The only thing that could be seen was a bowl filled with blood and brought by Timur. Eygu Timur goes to Faḍlallāh's assembly and tells him about the dream. Faḍlallāh smiles and tells Eygu Timur to 'go and tell his amir that he was not the one who had that dream. Go and tell him this and come back and tell me what he has to say.' Eygu Timur goes to Timur and tells him what happened. Timur asks who had this dream and what it meant. Eygu Timur visits Faḍlallāh again and tells him Timur's message. Faḍlallāh tells him that the dream belonged to the woman who had slept with Timur. The interpretation is that the woman took a lover when she was a virgin, but that man could not make love to her no matter how much he wanted to. One night, the woman could not sleep but the following night went into a deep sleep. The man took advantage of it and took her virginity. She realised what had happened and could not hide the truth as she was dressed all in white. Eygu Timur tells Timur of Fac̣lallāh's interpretation and Timur calls the woman and tells her that he would not harm her if she told him who took her virginity. The woman pleads for mercy. When Timur bestows his mercy, she tells him the same thing that

109 Sayyid Ishāa, Khw āb-nāma in Usluer, Hâbnâmeler, p. 208.

110 Shaykh 'Abbās Qomī, Mashāhir-i Dānishmandān-i Islām, Kitābfurūsh-i Islāmiya, Tehran 1350 H.sh., Vol. I, p. 34.

$111 \mathrm{Kh}^{w}$ āfi, ibid., Vol. III, p. 1112. 
Faḍlallāh said. Astounded, Timur bites into his shirt and tells Eygu Timur 'not to attend Fac̣lallāh's assembly anymore.' The book concludes this section as follows: 'His inner world was invaded by suffer and groundless fear of Faḍlallāh. At the end because of this fear he turned to be eternally blamed. la net Allāhi 'aleyhi ve 'alā atbā ihim ajma ${ }^{112}{ }^{12}$ '

Faḍlallāh's visit to Samarqand is an important event. Why did Faḍlallāh go to Samarqand during the reign of Timur? As we can understand from this dream, Timur knew Faḍlallāh at least by name if not because they met in Damghan in person. The fact that Timur told Eygu Timur to go and tell his 'master' about the dream and especially because he told him 'not to attend his assembly anymore' infers that Eygu Timur participated in Fậlallāh's assemblies and even pledged homage to him. Eygu Timur's inclusion in Faḍlallāh's circle may mean that Faḍlallāh affiliated with political authority to explain himself.

In Fā̄idān-nāma, Faḍlallāh notes that he saw Amīr Timur performing prayers in his dream. Faḍlallāh joined him in praying, and Timur rolled out his carpet for the dervishes ${ }^{113}$. In another dream that he had in a masjid in Baku on the third Monday of Șafar (in the year 796), he saw a dome and threads tied to it. This stands for Amīr Timur, his son, the earth, and the one who is above the earth ${ }^{114}$.

The fact that Faḍlallāh had these dreams in the year of his execution and that there is no other negative comment about Timur until the time that led to Faḍlallāh's execution gave rise to the thought that Mīrānshāh was more active in this process than his father, Timur.

\section{Later Developments}

Faḍlallāh seemingly could not find the peace and tranquillity that he sought in Samarqand. Indeed, he travelled to the south again because of the negative incidents that had occurred there. In his last trip to the south, as he was passing through Mashhad, Sayyid (Nizām al-Dīn) 'Abd al-Hayy (d. 829/1425)115, a prominent name in Mashad had a dream, and he invited Fac̣lallāh over for dinner to have his dream interpreted. Rejecting any food other than that prepared by the

112 Firishteoghlu, Tarjama-i Kh $h^{w} \bar{a}$-nāma in Usluer, Hâbnâmeler, p. 223.

113 Faḍlallāh Astarābādī, Jāvidān-nāma, f. 296b.

114 Faụlallāh Astarābādī, Jāuidān-nāma, f. 296b.

$115 \mathrm{Kh}^{\mathrm{w}}$ āfî, ibid., Vol. III, p. 1112. 
dervishes, Faḍlallāh agreed to eat in the house of Sayyid 'Abd al-Hayy. This shows how important 'Abd al-Hayy was in the eyes of Faḍlallāh.

In his dream, 'Abd al-Hayy saw large hailstones falling from the sky and turning into pearls upon touching the ground. He collected the pearls and put them in his lap. Someone showed up to tell him that no other person had such gemstones. Faḍlallāh told him that the dream had multiple interpretations, one of which he chose to tell him. 'Abd al-Hayy was in debt in those days, and he was spending more than he was earning. However, he would soon be relieved and repay his debts. When 'Abd al-Hayy asked about the other interpretations, Faḍlallāh answered that they were in a chapter of 'the Book'. As explained more explicitly in the Persian version of $K h^{w} \bar{a} b$-nāma, it is the book in which Faḍlallāh wrote about the big events that would take place in the next 30 years. According to the notes, the padiShāh of the era would send 'Abd al-Hayy to the governor of Gilan. The interpretation ends here.

The report continues in 'Abd al-Hayy's own words: 'Hadrat-i khiläfet-penāh, amīr-i sultān-zāda Shährukh khallede Allāhu saltanatahü' (referred to only as Shāhrukh in the Turkish translation) sent Sayyid 'Abd al-Hayy to Lahijan, one of the townships in Gilan, to Sayyid Riḍā Kiyā, the governor of Gilan. This dervish (the aforementioned pādshāh, i.e. Sayyid Riḍa Kiyā in the translation) asked for the book from Sayyid 'Abd al-Hayy in order to study it. 'Abd al-Hayy told him that the book was very precious and invaluable to them, and they therefore placed it in Imām Reḍā's tomb, but a fire broke out in the treasury causing it to burn down with the rest of the things ${ }^{116}$.

The fact that the text refers to Sayyid Riḍā Kiyā as 'this dervish' indicates that Kiyā was interested in sufism or Hurufism. Mar'ashī notes that Riḍā Kiyā was a unique man who had knowledge of religious and secular sciences and followed all kinds of other sciences of his time. To this end, it is possible that he knew about Hurufism and at least respected Faḍlallāh if he was not a follower. Previously, Riḍā Kiyā was the governor of Pashija, but in 799/1397 he took over the administration of Lahijan from his brother Sayyid Husayn Kiyā, and kept it until he died on Jumāda I 1, 829/20 March 1426 ${ }^{117}$.

116 Sayyid Isḥāq, Khwa ăb-nāma in Usluer, Hâbnâmeler, p. 134 and 136; Firishteoghlu, Tarjama-i Kh ${ }^{w} \bar{a} b-$ nāma in Usluer, Hâbnâmeler, p. 135 and 137.

117 Zāhir al-Dīn Mar'ashī, Tārn̄kh-i Gīlān ve Daylamistān, Iț̣ilāeāt, Tehran 1364 H.sh., pp. 111-146. 
While governing Lahijan, Rị̣ā Kiyā faced opposition from his cousin, Haydar Kiyā. Eventually, Haydar Kiyā, imprisoned in Pashija, escaped and served the council amirs of Timur for two years. Haydar Kiyā, escorted by an ambassador, was sent to Riḍā Kiyā and, as a result of some correspondence, Haydar Kiyā was given the administration of $\mathrm{Gawki}^{118}$.

It is noteworthy that Rị̣a Kiyā talked with Sayyid 'Abd al-Hayy, whom he asked for a book written by Faḍlallāh, and that he referred to him as 'this dervish'. Haydar Kiyā's name is mentioned in Faḍlallāh's testament. In his testament, Faḍlallāh strongly advises his children not to move to Mazandaran and Gilan, as he thinks that Haydar Kiyā's son and claimants would reveal their location and that they would then be killed ${ }^{119}$.

Noted in Fā̃idān-nāma, the dream that Faḍlallāh had in the Tokchi Imaret on Rabī' II 9, 792/4 April 1390 that showed his turban being taken off his head suggests that Isfahan was another of Faḍlallāh's stops during his last trip.

Mawlānā 'Izz al-Dīn Shāmī's dream that he had in Isfahan, as well as its interpretation, correspond to the same period of time. In his dream, Mawlānā 'Izz al-Dīn Shāmī saw that Shāh Manșūr came from Shiraz and attacked Isfahan, which was under the administration of his cousin Zayn al-'Ābidīn, but that he returned home without conquering it. In another dream, he came back to the city and besieged and captured it. When he told Faḍlallāh about his dreams, Faḍlallāh told him that everything he saw in his dreams would come true. This is indeed what happened ${ }^{120}$. In Āl-i Muzaffar's history, the siege and conquest of Isfahan by Shāh Manșūr took place in the years 792 and 793/1389-1391 ${ }^{121}$.

After Timur captured Isfahan from Zayn al-'Ābidīn in 788/1386-7, he appointed Hājī Beg and Yūsuf Shakh to be in charge as he had heard that Toqtamish Khan was about to attack Samarqand and Bukhara, and then left. Shāh Shujā's son Zayn al-'Ābidīn took over Isfahan. In Isfahan, a war broke out between Zayn al- 'Ābidīn and Shāh Manșūr of the Muzaffarids. Shāh Manṣūr was defeated and returned home. There was another battle between the two at the border of Isfahan and that

118 Zāhir al-Dīn Mar`ashī, ibid., p. 120.

119 Fatih Usluer, "Hurufism: The Faḍlallāh Family, Children, and Testament", Iranian Studies, p. 21.

120 Sayyid Ishāq, Kh' āb-nāma in Usluer, Hâbnâmeler, p. 146.

121 Mạ̣mūd Kutubī, ibid., pp. 128-131. 
battle resulted in Zayn al-'Ābidīn's escape to Ray ${ }^{122}$. Faḍlallāh was in Isfahan when Shāh Manșūr conquered the city as in stated in Shāmī's narration. Faḍlallāh's departure from Isfahan coincides with these events.

After Faḍlallāh left Isfahan, he stopped at Burujird, where, on a Wednesday night in Jumāda I, he had a dream in which he saw a lame man (most probably Timur) sending someone to capture and kill him. That person said: 'If one knows why he is being wanted, how is it possible for someone to have him brought in?' He finally captured and killed him but Faḍlallāh saw that he was still alive ${ }^{123}$.

\section{Execution of Fadlallah}

Faḍlallāh must have felt uneasy in conflict-ridden regions as he started moving north again. He was in Baku in 796/1393. Faḍlallāh and his companions were followed and inspected by soldiers in Baku. As the Baku elite refrained from engaging with the soldiers ${ }^{124}$, Faḍlallāh, his family, and his followers had to stay in tents on the island ${ }^{125}$.

We do not know how long they stayed in Baku, but we do have information about his interpretations and his dreams relevant to Baku. We learn from Ahmad Rustamdārîss report that some of his followers travelled to downtown Baku for certain needs that emerged after they settled on the island ${ }^{126}$.

The two dreams that Faḍlallāh had in Baku are noted in Fāovidān-nāma. In one of them, he saw God's house (i.e. the Ka'ba) on the Astarabad River while he was in the hammam there, telling people why they had to circumambulate the house seven times and why they had to turn their faces to the house when performing seventeen rak'ats of prayers. The people wore wool clothing and had spears ${ }^{127}$.

In the other dream that he had in a masjid in Baku on the third Monday of Safar in the year 796/22 December 1393, he saw a dome and threads tied to it. This stood for Amīr Timur, his son, the earth, and the one who is above the earth ${ }^{128}$.

122 Khwāndamīr, ibid., Vol. III, pp. 319-325.

123 Faḍlallāh Astarābādī, Jāvidān-nāma, f. 301b.

124 Firishteoghlu, Tarjama-i Khwāb-nāma in Usluer, Hâbnâmeler, p. 179.

125 Sayyid Isḥāq, Khº âb-nāma in Usluer, Hâbnâmeler, p. 178 and 180.

126 Sayyid Ishāā, Kha āb-nāma in Usluer, Hâbnâmeler, p. 178.

127 Faụlallāh Astarābādī, Jāvidān-nāma, f. 296a.

128 Faụlallāh Astarābādī, Jāuvidān-nāma, f. 296b.

Belleten, Ağustos 2021, Cilt: 85/Say1: 303; 463-505 
There is a report about the three dreams that Faḍlallāh had on one of the Baku islands (Jazira). The first of these dreams took place on Jumāda II 24, 796/26 April 1394 (including the date when he was there) on a Sunday, which is about four months before Faḍlallāh's death. In this dream, Faḍlallāh sees the sun rising from the west in Jazira. He realises that it is a sign of doomsday, and from that point on it does not matter if people profess their faith. Husayn Kiyā ${ }^{-129}$ was also there, and somebody said that Sayyid Shams al-Din wanted to reverse the sun. Faḍlallāh read the following couplet when the sun rose from the west:

'The morning of doomsday has arrived, the doomsday has arrived

They have played the drum of doomsday, the morning of doomsday has arrived ${ }^{130}$.'

The two other dreams that he had in Jazira are not dated. In one of them he sees Dhū al-qarnayn and Shaykh Hasan, and in the other Shaykh Manșūr ${ }^{131}$.

Faḍlallāh also travels to Shamakhi in Azerbaijan. He visits Qāọ̄i Bāyazìd-i Shamakhī (Qāẹ̄i Bāyazīd in Shamakhi in $K h^{w} \bar{a} b-n \bar{a} m a$ ) who had fallen ill. The Qāḍ̄ tells him that he recited the verse 'And We ransomed him with a great sacrifice, Al-Ṣāffāt/107, in his dream, and that he was saddened by it. Faḍlallāh tells him that he will heal, and that the dream is about him, and that they will sacrifice him instead. Qāḍ̄ cries and regrets telling him about his dream. Faḍlallāh tells him that it did not happen by his will. When Faḍlallāh returns to his post, he is captured and taken to Alinjaq ${ }^{132}$.

To understand which of the two likelihoods took place, i.e. visiting Qāẹī Bāyazīd in Shamakhi or visiting Qāḍ̄ Bāyazīd-i Shamakhī, we should consider the report mentioned in the Testament that explains Façlallāh's capture. According to the details there, when they arrived at the bank of the Kurd-i/Gird-i? Alam River, Faḍlallāh and Husayn Kiyā questioned 'whether the cavalry stationed on the other

129 That person was Ḥusayn Kiyā b. Nāqib/Naqīb, one of Faḍlallāh's caliphs. Fadlallāh's Caliphs, Millet Library, 'Alī Amīrī, Persian, No. 993, f. 104b. The name Husayn Kiyā is also mentioned in the testament. During his capture, Faḍlallāh asks Kiyā, who was with him, to take his younger daughter, and if Khwāja Fakhr al-Dīn does not appear, to take his older daughter from there. He wills that 'the dervishes there must not fall in respect for Re'iss and Kiyā in their missions.' Faḍlallāh sends his compliments to Dervīsh Kiyā and his family, and asks Kiyā’s wife or mother to be a mother to his daughters.

130 Faḍlallāh Astarābādī, Jāoidān-nāma, ff. 296b-297a.

131 Faḍlallāh Astarābādī, Jāuidān-nāma, ff. 296b-297a.

132 Sayyid Isḥāq, Kȟa ăb-nāma in Usluer, Hâbnâmeler, p. 190. 
side of the water were waiting for them'. When they arrived in Shamakhi, which Khwāja Fakhr al-Dīn knew about, they slept in the masjid. They woke him and Mawlānā Mạ̣mūd up and went to the vessel. 'I had also told them that this poor man would be captured and delivered, I knew what would happen but there was nothing to do as this was our destiny. Now my hope is that things will go well ${ }^{133}$.'

Thus, since according to the Testament, Faḍlallāh and his companions arrived in Shamakhi after passing the Kurd-i Alam River, we can assume that they visited Qādị Bāyazīd outside Shamakhi, somewhere on the west side of Kurd-i Alam River.

Thus, Faḍlallāh visited Qāộ̄ Bāyazīd and interpreted his dream by saying, 'You will heal, this dream is about me, they will sacrifice me instead', and came back to his post. At that moment, 'Alī Samāè Astarābādī (in Khº̄a-nāma 'Alī Semā' Astarābādī) ruled that he be arrested and taken to Alinjaq ${ }^{134}$.

Kursī-nāma ${ }^{135}$ speaks of 'Alī al-A'lā, Qāḍ̂̄ Shamakhī (referred to as qāộ̀-i mal'ūn-i Yazīd ve shamarkhū in the text), his amir Mīrānshāh, and Shaykh Ibrāhīm with nasty words, probably due to them being held responsible for Fậlallāh's death. The Shamakhī Qāộ̄ here, referred to as a Yazìd by 'Alī al-A'lā, is the person Faḍlallāh visited on his sickbed. In the book, he notes that 'his affinity with God was only a flare', which indicates that Faḍlallāh and Qāḍ̄ Bāyazīd were on good terms. Surely these lines also imply that Qāḍ̄ Bāyazīd was not a sincere Muslim. Āzhand notes that Qāộ̄ Bāyaz̄̄d might be the Khª̄ja Bāyazīd mentioned in Jāvidān-nāma ${ }^{136}$, but the Qāḍ̄ Bāyazīd in Shaykh Ibrāhīm's circle and Khwāja Bāyazīd Damghān̄̄-Faḍlallāh's father-in-law and former vizier mentioned in Jā̃idān-nāma - are not the same person; they only happen to have similar names.

There is no doubt that the order that instructed Faḍlallāh's capture was passed by Shaykh Ibrāhīm. Shaykh Ibrāhīm (d. 820/1417-8) was the $34^{\text {th }}$ ruler of the Shirvānshāhs that ruled Shirvan for centuries. When Timur was to attack Cumania via Darband in 788/1386, Shaykh Ibrāhīm pledged allegiance to Timur and, thanks to this pledge, he kept his post as the ruler of Shirvan ${ }^{137}$. Faḍlallāh's

133 Usluer, "Hurufism: The Faḍlallāh Family, Children, and Testament", Iranian Studies, p. 25.

134 Sayyid Ishāq, Khwāb-nāma in Usluer, Hâbnâmeler, p. 190.

135 'Alī al-A'lā, Kurs̄̄-nāma, Bibliotheque Nationale, Persian, No. 255, ff. $112 \mathrm{a}-\mathrm{b}$.

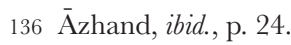

137 Vladimir F. Minorski, Tārīkh-i Shirvān and Darband, trans. Muḥsin Khādim, Bunyād-i Dā’ira-i 
presence in Shirvan coincides with the time when Shaykh Ibrāhīm tried to control the region after he pledged his allegiance to Timur.

We also know that the Shirvan Governor Amīr Shaykh Ibrāhīm had Faḍlallāh interpret his dream at an earlier date. In his dream, Amīr Shaykh Ibrāhīm sees himself shooting two cormorants (geese in the translation) with one arrow. Faḍlallāh interprets that he is planning to capture two people and that he will succeed. Amīr Shaykh Ibrāhīm asks him who these two people are while in his khalvat-khāna. Faḍlallāh tells him that he plans to invite the rulers of Shabran and Mahmud Abad and have them captured. Amīr Shaykh Ibrāhīm confirms that this is true, and soon carries out this $\operatorname{plan}^{138}$.

Faḍlallāh visits Qāộ̄ Bāyazìd, who had fallen ill in Shamakhi. On his way back to island he was captured in Baku by the soldiers waiting on the coast and imprisoned. Later he was executed in Alinjaq on 6 Dhū al-Qa'da, 796/2 September $1394^{139}$.

Ma`ārif-i Islāmī, Tehran 1375 H.sh., pp. 249-251; Khwāễ, ibid., Vol. III, p. 989.

138 Sayyid Ishāq, Kh'̄āb-nāma in Usluer, Hâbnâmeler, p. 196.

139 K'̀n dhū al-qa'da chu rūz-i nav shod

K'̀̄n dāse-i māh cān derū shod

Güya ki be-Cum'a rūz-i ākhir

Țüfān zi-tennūr geshte zāhir

'Alī al-A'lā, Qìāmat-nāma, Istanbul University Library, Persian, no. 1195, ff. 67a-b.

In the year of 796, the crescent of Dhū al-qa'da was seen on Saturday and Fadlallah was executed the first Friday of that Dhū al-qa'da which is 6 Dhū al-qa'da Thursday afternoon (that is Friday according to tradition). See 'Abdulbāqī Gölpınarlı, Hurufilik Metinleri Kataloğu, Ankara: TTK, 1989, p. 3; Muhammad 'Alī Tarbiyat, Dānishmendān-i Āzerbayjān, Tabriz: Bunyād-i Kitābkhāna-i Firdowsī 13??, p. 387; Ya'qūb Āzhand, Hurüfyya dar Tārn̄kh, Tehran: Ney, 1369 H.sh, p. 34; Shahzad Bashir, Fadlallāh Astarabadi and the Hurufis, Oxford: Oneworld, 2005, p. 41.

But 'Alī al-A'lā says (in Kursī-nāma, Bibliotheque Nationale, Persan, No. 255, f. 113b) that the first day of Dhū al-qa'da was Sunday (Ghurra-i Dhü al-qa'da yakshanba büd). So the sixth day is Friday without further interpretation as was done by Gölpınarlı and others.

Ghurra-i Dhū al-qa'da yakshanba būd

K'az Alinja āfitāb-i Haq numūd

...

Çārdah shod sāl az ān vaqt $-i$ shadīd

K'ān la '̌n-i nākis dīv-i 'añ̄d

'Alī al-A'lā, Kursī-nāma, Bibliotheque Nationale, Persan, No. 255, f. 113b.

The most clear evidence on the date of Faḍlallāh's execution on 6 Dhū al-qa'da is found in the elegy that 'Alī al-A'lā wrote for his brother:

Kushte ez-tārīkh fì u dād u lām

Be ìn Dhī al-qa'da yek bedr-i tām

Fadl-i Haq rā der-shesh ìn der hifdeh būd

Rù be khāk āverd u kerd $\bar{u}$ rā sujüd

Ali al-A'la, Firāq-nāma, Istanbul University Library, Persian, no. 1158, f. 62b.

Belleten, Ağustos 2021, Cilt: 85/Say1: 303; 463-505 


\section{Conclusion}

The prominent and powerful elites in Iran and Central Asia in the $14^{\text {th }}$ and $15^{\text {th }}$ centuries can be listed as military and local rulers, the 'ulamā', and the Shaykhs. In that period, statesmen, including Timur himself in particular, had a distinct respect for the 'ulamā' and the Shaykhs. Due to this, their public reputations increased and the rulers could control these people who were followed by the masses.

Certainly, not every single sufi or scholar were lucky enough to enjoy such favour. The conflict and contradictions between some sufis and political powers cannot be explained by superstitious beliefs alone. Indeed, even the things noted in the period chronicles about the Hurufis are not really relevant to the beliefs of Hurufism. The process that created animosity between the political powers and a sufi shaykh or a certain group formed the parameters of this article.

Faḍlallāh made positive contacts with several statesmen, scholars, and sufis. However, some of his relationships were not so positive. It seems that Faḍlallāh's interpretations influenced this matter. In addition, Faḍlallāh's growing number of followers and popularity, as well as his positive and respected relationships within political circles, might have disturbed certain people who had or had wanted to have close ties with the central power.

It is not difficult to predict that the disturbed group, who had a certain reputation before commoners and statesmen, conducted negative propaganda activities. The most effective negative propaganda in the eyes of the political power and the public was to fabricate lies about the targeted group, such as that they were planning to seize power or that they hold superstitious beliefs. The frisk conducted by law enforcers at the Hurufi lodge in Tabriz is the best example of this. However, we have no data indicating that Faḍlallāh emerged like a Mahdi similar to the persona in Shia with power in the world and afterlife.

There is no mention by Faḍlallāh's biographers, who quote his conflicts with certain people, that Faḍlallāh claimed to be the Mahdi or that he was subject to such an accusation or an attack due to his beliefs. In our study, we tried to prove that Faḍlallāh did not pursue power by claiming to be the Mahdi or some kind of religious leader.

Nevertheless, we see that Faḍlallāh's extremely favourable relationships within political circles started to deteriorate after a certain point, particularly because of the influence of the 'ulamā' and sufi circles. Even though Faḍlallāh looked for 
ways to directly contact Timur to explain himself so that he could live in peace, he did not have this opportunity despite establishing strong relations with several soldiers and statesmen from Timur's inner circle.

We found that the era's soldiers, bureaucrats, 'ulamā', and men of the cloth changed their attitudes according to the frequently changing dominant power, and that the boundaries between the parties were not at all straightforward. Similarly, Faḍlallāh tried to maintain a consistent relationship with the present administration, and when he perceived a social or political threat, he chose to leave.

Faḍlallāh's execution marks the beginning of a very difficult period for Hurufis. Some revolted against the injustice, some abandoned their homeland, and some were imprisoned. However, the Hurufis did not disappear. They found new places to settle further west, particularly in Anatolia and the Balkans, engaged in different sects, and maintained a presence until the $20^{\text {th }}$ century. This presence continues in some form until today. 


\section{BIBLIOGRAPHY}

Abrū Ḥāfiẓ-i, Zubdat al-Tavārīkh, ed. Sayyid Javādī, Vazārat-i Farhang u Irshād-i Islāmī, Tehran 1380 H.sh., Vol. I-IV.

Abțahī, Mīr Sayyid Hujjat Muvaḥhid, Rīshahā ve Filvehā-yi Tashayyu've Havza-i Ilmiyya-i Isfahān der țūl-i Târrīkh, Daftar-i Tablīghāt al-Mahd̄̄, Isfahan 1376 H.sh., Vol. I-III.

'Alī al-A'lā, Kursīināma, Bibliotheque Nationale, Persan, No. 255.

'Asqalān̄̄, Ibn Ḥàjar, Inbā' al-ghumr bi-abnā' al-\{umr, Ihỵā al-Turāth, Cairo 1415/1994, fas. II, p. 219.

Astarābādī, Faḍlallāh, Jāòidān-nāma, Millet Library, 'Alī Amīrī, Persian, No. 1046

Astarābādī, Faḍlallāh, Vasiyat-nāma, Millet Library, 'Alī Amīrī, Persian, No. 1009.

Āzhand, Ya'qūb, Hurufyyya dar Tārikkh, Ney, Tehran 1369 H.sh.

Bashir, Shahzad, Fazlallah Astarabadi and the Hurufis, Oneworld, Oxford 2005.

Binbas, Ilker Evrim, "The Anatomy of a Regicide Attempt: Shāhrukh, the Hurufis, and the Timurid Intellectuals in 830/1426-27", $7 R A S$, XXIII (2013), pp. 391-428.

Chahārdah Risāla-yi Färsī az-Șā in al-Dīn 'Al̄̄ b. Muhammad Turke-yi Isfahāñ̄, ed. S. A. M. Bihbahānī and S. I. Dībājī, Taqī Sharīf Riḍā̄è, Tehran 1351 H.sh.

Davlatshāh, Tadhkirat al-Shu'arā, ed. E. Brown, Brill, Leiden 1900.

Fadlallāh's Caliphs, Millet Library, 'Alī Amīrī, Persian, No. 993, f. 104b.

Farrukh, Rukn al-Dīn Humāyūn, Hāfiz-i Kharābātū, Asātịi, Tehran 1361 H.sh., Vol. I-VIII.

Firishteoghlu, 'Abd al-Majīd, Tarjama-i Khwāb-nāma, I.B.B. Ataturk Library, 'Othmān Ergin Manuscripts, No. 1321.

Gölpınarlı, Abdülbaki, Hurûflik Metinleri Katalogu, TTK, Ankara 1989.

Gölpınarlı, Abdülbaki, "Faḍl-Allah Ḥurūfî”, El2, Vol. II, pp. 733-735.

Khª̄āî, Fașịh, Mujmal-i Fașīhī. Ed. Sayyid Muhsin Nājīi Naṣr-ābādī, Esātịir, Tehran, 1386 H.sh., Vol. I-III.

Kh"āndamīr, Tārīkh-i Habīb al-Siyar, Kitābfurūshī Khayyām, Tehran 1362 H.sh., Vol. I-IV. 
Kiyā, Șādiq, Vāzhanāma-yi Gurgāñ̄, Dānishgāh-i Tehrān, Tehran 1330 H.sh.

Kutubī, Maḥmūd, Tärīkh-i āl-i Muzaffar, Amīr Kabīr, Tehran 1364 H.sh.

Manz, Beatrice, Power, Politics and Religion in Timurid Iran, Cambridge University Press, Cambridge 2007.

Maqrizī, Durar al- «qūd al-farìda fì teräjim al-a\}yān al-mufìda (Beirut, 1423/2002).

Mar'ashī, Zāhir al-Dīn, Tārn̄kh-i Gīlān ve Daylamistān, Ițtilāeàt, Tehran 1364 H.sh.

Melvin-Koushki, Matthew S., The Quest for a Universal Science: The Occult Philosophy of Să in al-Dīn Turka Isfahan! (1369-1432) and Intellectual Millenarianism in Early Temürid Iran, PhD Dissertation, Yale University 2012.

Minorski, Vladimir F., Tārn̄kh-i Shirvān and Darband, trans. Muhsin Khādim, Bunyād-i Dā’ira-i Mac̄āiffi Islāmī, Tehran 1375 H.sh.

Mir-Kasimov, Orkhan, Faḍlallāh Astarābādī, EIr.

Mir-Kasimov, Orkhan (ed.), Unity in diversity. Mysticism, messianism and the construction of religious authority in Islam, Brill, Leiden 2013.

Mir-Kasimov, Orkhan, "Le 'Journal des Rêves' de Fadlullah Astarabadi: Edition et Traduction annotée", Studia Iranica XXXVIII (2009), pp. 249-304.

Nāfajī, Khwāb-nāma, Vatican Library, Persian Manuscripts, No. 17.

Nuṣayrī, Muhamammad Riḍā, Asar-i Âferīnān, Anjuman-i Āṣār u Mafākhir-i Farhangī, Tehran 1384 H.sh., Vol. I, p. 299.

Qazvīnī, Muhammad Yūsuf Vāleh Iṣfahānī, Khuld-i Berīn: Sections 6-7, ed. Mīr Hāashim Muhaddith, Amīr Kabīr, Tehran 2001.

Qomī, Shaykh 'Abbās, Mashāhir-i Dānishmandān-i Islām, Kitābfurūsh-i Islāmiya, Tehran 1350 H.sh., Vol. I, p. 34.

Ritter, Hellmut, "Studien zur Geschichte der Islamischen Frömmigkeit: Die Anfange der Hurufisekte", Oriens, no. 7, June 1954 trans. H. Mu’ayyad, Farhang-i İān Zemìn, no. 10, 1341 H.sh., pp. 319-393.

Roemer, H.R., "Temür in Iran", in The Cambridge History of Iran, ed. P. Jackson, L. Lockhart, Cambridge University Press, Cambridge 1997, Vol. VI, p. 70.

Rūmlu, Ahsan al-Tavārīkh, ed. 'Abd al-Ḥusayn Navā'ī, Asāṭ̣ir, Tehran 1384 H.sh., Vol. I, p. 213. 
Sakhawī, Al-daw’ al-lāmi`a li-ahl al-qarn al-tāsi`a, Dār al-ghayb al-Islāmī, Beirut 1412/1992), Vol. I-VI.

Sayyid Isḥ̄āq, Khَ̄āb-nāma, Millet Library, 'Alī Amīrī, Persian, No. 1042.

Sayyid Isḥāq, Mahram-nāma, Millet Library, 'Alī Amīrī, Persian, No. 1031.

Smith, John M., History of the Sarbadar Dynasty: 1336-1381 A.D. and its sources, Mouton, The Hague Paris 1970.

Şıxıyeva, Səadət, "Hürufiliyin tarixi: ənənəviləşmiş təhriflər, unudulmuş gerçəkliklər”, Metafizika I/2 (2018), pp. 65-96.

Usluer, Fatih, Hurūfilik; Ilk Elden Kaynaklarla Doguşundan Itibaren, Kabalci, Istanbul 2009.

Usluer, Fatih, "Hurufism: The Faḍlallāh Family, Children, and Testament", Iranian Studies, DOI: 10.1080/00210862.2020.1777393 (2020).

Usluer, Fatih, Hâbnâmeler, Kut, Çorum 2020. 
